IZA DP No. 7468

Determinants of Immigrant Homeownership:

Examining their Changing Role during the Great Recession and Beyond

Kusum Mundra

Ruth Uwaifo Oyelere

June 2013 


\title{
Determinants of Immigrant Homeownership: Examining their Changing Role during the Great Recession and Beyond
}

\author{
Kusum Mundra \\ Rutgers University \\ and IZA \\ Ruth Uwaifo Oyelere \\ Georgia Institute of Technology \\ and IZA \\ Discussion Paper No. 7468 \\ June 2013 \\ IZA \\ P.O. Box 7240 \\ 53072 Bonn \\ Germany \\ Phone: +49-228-3894-0 \\ Fax: +49-228-3894-180 \\ E-mail: iza@iza.org
}

Any opinions expressed here are those of the author(s) and not those of IZA. Research published in this series may include views on policy, but the institute itself takes no institutional policy positions. The IZA research network is committed to the IZA Guiding Principles of Research Integrity.

The Institute for the Study of Labor (IZA) in Bonn is a local and virtual international research center and a place of communication between science, politics and business. IZA is an independent nonprofit organization supported by Deutsche Post Foundation. The center is associated with the University of Bonn and offers a stimulating research environment through its international network, workshops and conferences, data service, project support, research visits and doctoral program. IZA engages in (i) original and internationally competitive research in all fields of labor economics, (ii) development of policy concepts, and (iii) dissemination of research results and concepts to the interested public.

IZA Discussion Papers often represent preliminary work and are circulated to encourage discussion. Citation of such a paper should account for its provisional character. A revised version may be available directly from the author. 


\section{ABSTRACT \\ Determinants of Immigrant Homeownership: Examining their Changing Role during the Great Recession and Beyond}

The Great Recession had significant economic effects both in the U.S. and around the world. There is evidence that homeownership rates declined during this period, though some immigrants were less severely affected compared to natives. In this paper we investigate the role of several factors in reducing the vulnerability of immigrants in the face of the economic crisis and increasing the probability of their homeownership. Specifically we examine to what extent birthplace networks, savings, length of stay in the U.S., and citizenship status affect the probability of homeownership before the recession and to what extent these impacts have changed since the recession. Using data from Current Population Survey for the years 2000 - 2012 our results suggest that birthplace networks have a significant effect on homeownership and this effect further increases after the onset of recession. Moreover the impact of birthplace network on homeownership is stronger for citizens and those who are not recent immigrants. We also find a decline in the impact of saving and length of stay on the probability of homeownership during 2007-2012 compared to earlier years. In contrast we find an increase in the impact of being a citizen on immigrant homeownership during this period.

JEL Classification: R20, R23, J11, J15

Keywords: birthplace networks, home ownership, Great Recession, savings, years in the U.S., citizenship status

Corresponding author:

Ruth Uwaifo Oyelere

School of Economics

Georgia Institute of Technology

221 Bobby Dodd Way

Atlanta, GA 30332

USA

E-mail: ruth.uwaifo@econ.gatech.edu 


\section{Introduction}

The Great Recession is acknowledged to be the most devastating global financial crisis of recent times and the effect of this recession will be felt for many decades to come. A common belief is that the housing market played a key role in triggering the Great Recession by a failure of the risky mortgage markets and subprime loans. The widespread relaxation of the credit constraints and underwriting practices leading to excess leveraging of the homeowners during the housing boom led to an excessive foreclosure and great loss of personal wealth (Ellen and Dastrup 2012). The Great Recession is believed to have left many people with vast losses in potential income, retirement income, and led to wealth gaps that could last for generations to come. Recent evidence like Ownens and Sampson (2013) suggest heterogeneity in the impact of the recession with greater negative effects in communities with higher concentrations of minority and immigrant residents.

There is clear evidence from the U.S census data that homeownership rates declined during the Great Recession. However recent evidence suggests heterogeneity in that decline across groups (see Mundra 2013 and Painter and Yu 2012). Painter and Yu (2012) finds that the early impact of the recession across the U.S has been more severe on native-born than on immigrants. We also note a similar trend in our analysis using data from the Current Population Survey (CPS) though over a longer period of time (see Table 1). Specifically, while natives experienced a decline in homeownership from $74.27 \%$ between $2000-2006$ to $72.42 \%$ (2007-2012) immigrants on average experienced an increase from $52.41 \%$ to $54.32 \%{ }^{1}$ Given immigrants experienced greater negative wage decline since the recession than natives and yet on average seem to have experienced no decline in homeownership while natives have, it is useful to focus on the factors that affect homeownership for immigrants and the changing role of these factors since the recession. ${ }^{2}$

There are other reason why we focus our analysis solely on immigrants. First, there is already a well known income, wealth, housing cost, financial instrument differences among natives compared

\footnotetext{
${ }^{1}$ National Bureau of Statistics (NBER) states that the Great Recession lasted for 18 months from December 2007 June 2009. Our table break down into two period does not isolate this period but shows rates for before the recession and from the recession onward.

${ }^{2}$ Data trends noted from March CPS data 2007-2012
} 
to immigrant groups in the U.S. Given these pre-existing differences and unique characteristics of immigrants, isolating impact in a general analysis of all individuals in the U.S may be difficult given potential selection bias. This is especially true when issues related to networks, social capital, coping mechanisms and vulnerability are central issues being discussed. Second, immigrants have been substantial drivers of the housing demand in the U.S. (Simmons 2001) and a recent report predicts that even after the 2007 collapse and subsequent stagnation of the housing market, immigrants based on the demographic projections in the U.S. will continue to fuel the housing demand through 2020 (see Myers and Pitkin 2013). Hence focusing on homeownership among immigrant is very relevant and timely.

In this paper, we particularly focus on the role of immigrants' savings, immigrants' networks, years in the U.S., and U.S. citizenship on homeownership and how these factors could potentially cause the Great Recession to have heterogenous effect on homeownership. More generally these factors reduce individuals' vulnerability and increase their probability of homeownership based on theoretical foundations in the housing, network and social capital literature. We ask three specific questions. First, has the impact of savings, years in the U.S., and U.S. citizenship, on homeownership probabilities changed since the recession? Second, what is the role of birthplace networks on the probability of owning a home before the recession and has this impact changed over time? Third, to what extent does the impact of birthplace networks exhibit heterogeneity based on citizenship status, recent immigrant status and region of birth and has the recession changed this impact differently across different immigrant groups. ${ }^{3}$

Using a larger representative sample of immigrants in the U.S. from the March Current Population Survey (CPS) derived from Integrated Public Use Micro-data Series (IPUMS) from 2000-2012, we examine the changing role of these factors overtime using a probability model. We address potential endogenous effects using several controls and fixed effects. Specifically, we estimate the marginal effects of each of these factors in reducing vulnerability and increasing immigrant homeownership. In addition, we divide our sample into two periods: the first period is before the Great

\footnotetext{
${ }^{3}$ The immigrant groups referred to here are recent and non recent immigrants; citizens and noncitizens; and birth place regions.
} 
Table 1: Homeownership Rates: Pre and Post the Great Recession

\begin{tabular}{ccc}
\hline \hline & Immigrant & U.S born \\
Period & Rate & Rate \\
\hline Pre Recession & (Standard Deviation) & (Standard Deviation) \\
(2000-2006) & $52.41 \%$ & $74.27 \%$ \\
Recession and onward & $(0.50)$ & $(0.44)$ \\
$(2007-2012)$ & $54.32 \%$ & $72.42 \%$ \\
\hline \hline
\end{tabular}

Recession (2000-2006) (henceforth BGR period) and the second period focuses on the year the recession started and afterwards (2007-2012)(henceforth GRA period). We then estimate the change in the impact of these factors between the two periods using an interaction between recession and each variable. Finally to answer our third question we include in our model a triple interaction term capturing the recession, birthplace networks and each of the following factors: citizenship status, recent immigrants (less than 20 years in the U.S) and birthplace regions.

Our main findings show a decline in the role of savings in predicting homeownership which is robust to alternative ways of measuring savings as highlighted in our descriptive section. Furthermore, we find that the importance of citizenship for homeownership increases marginally over time and the effect of length of stay on the probability of homeownership has declined between the two time periods, though the decline is minimal. Our results suggests that birthplace networks are important for homeownership and is the only housing determinant for which we note a substantial change in its impact on homeownership during the recession and onwards. The effect of birthplace networks increased sizeably from the recession onwards. This result suggest that individuals leveraged their network more during the recession to either keep their preexisting home or in purchasing homes post the crises. We also note that the effect of birthplace networks is not only heterogenous over time, but varies across citizenship status and years in the U.S. In particular we find that the effect of birthplace networks are stronger for citizen and significantly lower for recent immigrants. We also note heterogeneity in the impact of the effect of birthplace networks across major birthplace regions we consider. We however do not find evidence of heterogeneity in the change in the impact 
of birthplace networks for these factors between the two periods. Our results suggest that while the effect of birthplace networks changed significantly between these periods, the change did not differ based on these factors.

This paper makes an important contribution to the immigrant housing literature by highlighting the role of birthplace networks in immigrant homeownership and potential wealth creation (Alba and Logan 1992; Krivo 1995). Moreover, this paper also highlights the changing role of these networks for immigrants from the great recession onwards. Finding an increase in the impact of birthplace networks provides suggestive evidence on the role of networks in the time of stress and financial vulnerability. We also showcase the declining role of savings and length of stay as predictors of homeownership. The past literature has examined the the Great Recession and its impact on homeownership and recent papers have examined the importance of savings during the recession. However, the changing importance of factors like individuals' network and immigrant status both of which are correlated with how well individuals cope during crises have not been examined extensively. Our paper fills this gap.

Our results have policy relevant implications given the effort of the U.S government to revitalize the housing market and increase homeownership rates again. Given current research which suggests that substantial increases in demand for homeownership in the future will be driven by immigrants (Myers and Pitkin 2013), and given the unique challenges immigrants face and the mechanisms they may employ to prevent homeownership loss and increase the chances of homeownership; identifying factors that affect their housing outcomes and how such factors have changed over time is useful in designing programs to target these groups.

The rest of our paper proceeds as follows. In section two we review the past relevant literature on housing, network and assimilation. Section three is a summary of the data sets we used in this paper. In section four, we provide descriptive analysis of the data. Our empirical model is in section five, and section six provides a detailed summary of our finding and robustness checks. We conclude in section seven. 


\section{Relevant Background and Literature Review}

Loss of homeownership and housing wealth was not experienced homogenously across various groups in the U.S. Popular press and some reports using national data have shown that Black and Hispanic population had the most declines in homeownership and housing equity (Ellen and Dastrup 2012, Kochar 2009, Mundra 2013). There is increasing evidence, both from the news articles and academic research, that many home loans during the recent housing boom, particularly the subprime loans, were predatory in nature and were concentrated in minority and poor neighborhoods (Mayer and Pence 2008, Mayer et. al. 2009, Avery et al 2008, Dymski 2005, Renaurt 2004; Daglish 2009, Ho and Pennington-Cross 2006. Using Home Mortgage Disclosure Act of 1975 (HMDA) data for the year 2004, Bocian et al. (2008) find that the African-American and Latino borrowers are more likely to receive a higher priced subprime home loan than the white borrowers. ${ }^{4}$ In summary during the housing mortgage market leading to the Great Recession, the characteristics of the borrowers in the subprime market varied; however, they were disproportionately minority, lower income, older, less educated, financially less sophisticated and less likely to search for the best interest rates when applying for a mortgage. As a result, they were unable to comprehend the complex subprime securitization market and loan instruments that accompanied the recent housing market Lax et al. 2008; Courchane et al. 2004.

Though, not much is known about how immigrants fared generally during the Great Recession and afterwards, or whether certain immigrants coped with the housing crises better than others; two recent papers provide a window into how immigrants fared during the crises. Painter and $\mathrm{Yu}$ (2012) using the 2006 and 2009 American Community Survey (ACS) suggest that the effect of the recession on immigrants has not been as severe. They emphasise the role of location in this result noting that in destinations where immigrants are newest, reductions in homeownership was minimal in contrast to areas where immigrants had tended to concentrate in the past (immigrant gateways).

\footnotetext{
${ }^{4}$ There is also evidence of interest rates varying across neighborhoods; using a nationally representative single-family mortgage sample; Nothaft and Perry(2002) find that borrowers in a low-and moderate income neighborhoods usually pay 2-4 basis points more for 30-year loans. Also, many new homeowners purchased their homes with adjustable rate mortgage that typically re-set to a higher interest rates after the initial 2-3 years Bair(2007).
} 
In a recent paper using the 2009 American Housing Survey, Mundra (2013) shows that natives experienced higher homeownership gains than immigrants during the housing boom. However, she finds that the exit from homeownership is higher for immigrants than natives, though naturalized immigrants fared better during the housing bust than their non-naturalized counterparts.

The past literature also suggest that the path to homeownership is very different for various immigrant groups in the U.S. Mainly because of differences in their economic assimilation, legal status, geographic location, and wealth constraints (Coulson 1999, Borjas 2002, Painter et al. 2001, Diaz McConnell and Marcelli 2007, and Diaz McConnell and Redstone Akresh 2008, McConnel and Akresh 2010). Different immigrant groups not only have different financial wealth but they also differ in their choices of financial instruments as well as their confidence in the financial markets (Osili and Paulson 2007, 2009; Ketkar and Dora 2011). Immigrants also substantially differ in wealth transfers from their home country. Yu (2006) showed that the precondition of economic assimilation and acculturation into the U.S. society did not hold for many young Taiwanese immigrants during the eighties and nineties; primarily because of wealth transfers from their home country facilitating down payment for their homes. In a recent paper using data from the $2003 \mathrm{New}$ Immigrant Survey McConnell and Akresh (2010) show that housing cost burden varies among the legal immigrants in the U.S. by the country as well as the region of origin.

\subsection{Determinants of Homeownership : in the Context of the Great Recession}

The vast literature on homeownership in general and for immigrants in particular have identified some key factors that determine homeownership in the U.S. and potentially wealth creation. In this paper we focus solely on savings, immigrant networks, years in the U.S., and citizenship.

\subsubsection{Savings}

There is an extensive literature that highlights the important role of wealth as a determinant of homeownership. In the U.S. financial constraints particularly the money for down payment over 
and above a regular income plays a crucial role in explaining low homeownership (Linneman and Wachter 1989, Di and Liu 2007). For immigrant populations in the U.S. wealth constraints are particularly more acute compared to natives given the native immigrant income and wealth gap (Bauer et al. 2011; Hilber and Liu 2008). In a recent study Bohn and Pearlman (2013)show that the incidence of banking is $13 \%$ higher among natives than immigrants in the U.S. In addition Osili and Paulson (2007) using 2001 Survey of Income Participation data show that the immigrant-native wealth gap is also driven by the lower participation of the immigrants compared to natives in the mainstream financial markets. They find that $79 \%$ of native households have savings or checking account whereas only $68 \%$ of immigrant household have any sort of bank account. This disparity is further increased when the assets gets more riskier and forward looking. Specifically they find that $15 \%$ of immigrants have an IRA account compared to $30 \%$ of natives and $34 \%$ of natives own a stock whereas the figure is only $20 \%$ for immigrants. The wealth gap between natives and immigrants and low use of mainstream financial institutions by immigrants further makes the wealth constraint an important hurdle in immigrant homeownership.

Among immigrants in the U.S. there are wide differences in their bank use and economic assimilation. The unbanked status of immigrants in the U.S. are often found to be correlated with low education, family size, low income and wealth and low confidence in the financial institutions and various financial vehicles (Osili and Paulson 2006, Rhine et al. 2006, Paulson and Rhine 2008, Chatterjee 2009). Using New Immigrant Survey Osili and Paulson (2007) show that among the recently legalized immigrants a higher proportion of immigrants who have checking account and who own stock in the U.S. also own wealth abroad. The attitude towards financial institutions and the choice of financial instruments are often dependent on the quality of the institutions in the immigrants' home country (Osili and Paulson 2008).

Another potential buffer for immigrants during periods of crises is using income from their home country. This fund transfer often happens through the ethnic banks or through individual family transfers. Further during economic crises, some immigrants, unlike natives, may increase their disposable income by decreasing the remittances sent to their home country. This kind of 
reallocation of resources peculiar to immigrant could serve as a short term transitory income buffer in the face of economic crisis.

\subsubsection{Immigrant Networks}

Immigrants rely on social networks, particularly on their compatriots for their economic as well as social assimilation in the U.S. The literature has established a robust and significant positive effect of immigrant networks on the immigrants' labor market outcomes (Chiswick and Miller 1996; Munshi 2003; Amuedo-Dorantes and Mundra 2005 to name a few). Patel and Vella (2013) in a recent paper further show that networks have a strong effect on immigrants' occupational choice and wages. Using U.S. census data they show that the occupational choices of new immigrants are driven by the occupation of their compatriots and immigrants who choose the popular occupation have a larger and positive earning effect.

There is evidence that immigrant networks also serve the financial needs of immigrants' community and have a significant positive effect on the wealth creation and housing outcomes. Shanmuganathan at al. (2004) show that main ethnic groups in the U.S. actively provide banking needs to individuals, families and small businesses. Li et al. (2002) show that the rapid increase in the immigrant population in the U.S. has led to a rise in the ethnically owned banks and that these banks are playing an important role on the local community development. In particular they show that the Chinese ethnic banks have played a significant role in altering the residential and commercial infrastructures in Los Angeles Counties such as Chinatown and the San Gabriel Valley ethno-urban area. They also show that during 1992 - 1998 almost $71 \%$ of the housing loans approved by these banks were to Asian Americans and only 17\% were to whites. Many immigrants, either due to less education and limited English language skills feel at ease banking with their ethnic banks in the U.S.

The role of social capital in removing credit constraints and improving the chances of homeownership is not restricted only to the U.S. population. In a recent paper Yamamura (2011) shows that 
for Japan after controlling for unobserved area-specific fixed effects and various individual characteristics, homeownership and length of residence are positively related to investment in social capital by the individuals.

The recent literature on foreclosure and loss of homeownership have shown that disproportionately larger proportion of minorities and immigrant households who obtained loans during the peak subprime period have lost their homes (Allen 2009; Mundra 2013). Both Mundra(2013) and Kochar (2009) find that many immigrants, particularly Hispanic immigrants were more adversely effected compared to Hispanic natives. However, Mundra (2013) using American Housing Survey shows that naturalized Hispanic immigrants have a lower exit from homeownership than their non-naturalized counterparts and Painter and Yu (2012) using American Community Survey find that recent immigrants who settled in new immigrants centers were less adversely effected in their homeownership outcomes than the immigrants in the established gateway immigrant centers. This paper proposes that a possibly part of the explanation for this trend is immigrants' social capital in the U.S. through their birthplace networks and their usage of ethnic banks. Suggesting that the very reasons that prevent the financial and cultural assimilation of immigrants might also be their insurance in the face of an economic crisis. This paper argues that immigrant networks have possibly helped immigrants in obtaining more flexible home mortgage loans and access to community resources has helped in maintaining their homeownership and/or assisted immigrants in purchasing homes during and after the crises.

In this paper we measure birthplace network at the state level. Painter and Yu (2012) measure networks by the percent of immigrant group who are not linguistically isolated and speak English well and the percentage of immigrants in the metropolitan area that have been in the United States more than 10 years. Our paper differs from Painter and Yu's in four main ways. First, we focus on birthplace networks versus other definition of networks as immigrants from an individual's birth country are a plausible group an immigrant can credibly leverage during a crises. In contrast, a measure of an immigrant's network based on the size of immigrants in a metro area may not be as effective in capturing who immigrant may be able to depend on during a crises period. Social group 
formation and membership are typically at country level or lower and not based on individuals being immigrants. Moreover this helps in differentiating the pure network effect instead of the effect of upward mobility of the immigrant group. Second, we focus on the heterogeneity in the impact of birthplace networks based on citizenship status which is not considered by Painter and Yu. Third, we control for the effect of savings while examining the effect of birthplace networks. Lastly, we focus on a longer period from 2000-2012 and are able to deal with potential heterogeneity across states and time using fixed effects. Moreover our difference in difference methodology is typically preferred over a comparison of two cross-sections.

\subsection{Assimilation}

The longer the immigrants reside in the U.S. the more economically and financially assimilated they are and this may have an increased impact on their homeownership (Coulson 1999; Alba and Logan 1992; Krivo 1995). Not only upward income mobility but more years in the U.S. helps immigrants in their financial assimilation and gives them an opportunity to better understand the housing market

in the U.S. The literature on economic assimilation and social integration of immigrants have also shown that residing in large immigrant neighborhoods may often slow the immigrant human capital and English language skill accumulation (Chiswick and Miller 1996).

\subsection{Citizenship}

It is well known that immigrants legal status as well as citizenship helps in their homeownership (Borjas 2002; Coulson 1999, Clark 2003, Krivo and Kaufman 2004, Toussaint-Comeau and Rhine 2004, Dorantes and Mundra 2013). A immigrant with a U.S. citizenship might have less difficulty in securing a good housing loan and may potentially have a higher homeownership due to a greater security and permanence in the U.S. 


\section{Conceptual Framework: The Role of Networks in Coping with the Recession}

As highlighted above, the Great Recession had dramatic effects on individuals and families. However as with any shock, individual and families cope during such periods using different mechanisms. During the recession there was a significant job loss for many families. Given these losses many families where at risk of losing their homes. An important question is how they were able to survive this period. Using savings is one way individuals cope with shocks but given low levels of savings on

average in the U.S, the extent to which individual's savings can be leveraged to reduce vulnerability and home ownership loss during the recession may be attenuated - more so for immigrants.

Leveraging your network is one possible way individuals especially immigrants could have coped with the crises. In a recent paper Alsenia and Giuliano (2013) show that strong family ties may slow down faster economic growth of the household but does provide relief at the time of stress. So even if networks may hinder economic assimilation, they might become crucial for immigrant household in the labor and housing market during a period of stress such as the Great Recession. In this paper we measure immigrant networks by the percentage of the population from the immigrants' birth country at the state level.

The concentration of immigrants with similar characteristics as an immigrant can have a positive effect on homeownership or may adversely affect homeownership. For instance in the areas where there are more earlier established immigrants or if there are more Spanish speaking population, there is a possibility of more Spanish newspapers and more information flows on housing availability and better understanding of financial institutions. In such areas there are more ethnic banking that might potentially improve immigrants housing outcomes. On the other hand there is a possibility of overcrowding and more competition for the existing housing stock within these environments which may lead to lower homeownership if immigrants have strong preference for living within those enclaves.

In this paper we measure immigrant networks at the state level. For each immigrant in each year 
of data, we calculate the share of a state's population that is from that individual's birth country. Immigrants tend to live in enclaves and keep in touch with others from their home countries through social activities and associations - possibly spread through the state. Under financial stress, as experienced by many households in the recent financial meltdown and subprime crisis immigrants could rely on their social networks, both family ties and ties with their compatriots, for income and financial support. Possibly banking with the ethnic and community banks protected some immigrants from adverse mortgage vehicles or gave them some buffer and prevented foreclosure when the home values fell. So immigrant networks may help in sustaining immigrant homeownership.

The need to leverage immigrant networks when buying a home may also have become more important since the recession as lenders tightened lending restrictions like maximum loan-to-value ratios. During the housing boom individuals had the option to buy a home with minimal or no down payment, but since the recession significant down payments are required for most loans. Unfortunately for many families, saving the money for a down payment is the biggest obstacle to homeownership. Although some government programs exist for homebuyers that can reduce this down payment to between $3-5 \%$ of the home value (low down payment mortgages), this is still a substantial amount for many individuals especially if the individual lives in cities or suburbs where average housing cost is high. ${ }^{5}$ When a family's savings cannot cover this down payment, they usually seek help from family members or members of their network.

It is possible to assume that a large immigrant's birth network in an area increases the possibility of receiving assistance from this network during a crises. However, there are arguments that suggest otherwise. A large concentration of people from a particular birthplace in a location may not feel the need to form associations and clubs that bring the community together. Without such clubs and associations, there may be minimal group cohesiveness among immigrants from the same birth country. Moreover social sanctioning if a member does not provide help for others may not exist

\footnotetext{
${ }^{5}$ Low down payment mortgages are those for which mortgage insurance is required which protects the mortgage lender. The mortgage insurance can be provided by private companies or the government. The Federal housing authority (FHA) insures many government loans. FHA's minimum effective down payment is less than 3 percent but there is a limit on the loan amount that varies according to geographic area.
} 
which may suggest that the group may be harder to depend on during periods of crises. In contrast, immigrants with a smaller population from their home country within an area may feel the need to form associations or clubs. These associations tend to build trust among members and social sanctioning of members who act against norms may be a credible threat within these groups. Trust fosters social capital accumulation which can make such networks more dependable for an immigrant especially during a period of crises

Despite the possibility that larger networks can be less cohesive, we hypothesize that the larger the percentage of immigrants residing from an immigrants home country in the state, the larger the network an individual can leverage from during a crises to meet any of the needs highlighted above. This is because a larger network size increases the possibility that there could be mutual insurance. Meaning that an any time $t$ when individual $i$ have a negative shock, there would be someone $j$ who this individual $i$ can leverage and will be willing to help. ${ }^{6}$ Assuming that some form of mutual insurance is available via an immigrant's network, then the larger the network the greater the probability of homeownership at any given point in time. This will imply a greater possibility that there would be someone who would be available to assist in buying a home. We also hypothesize that the effect of these networks will increase during the recession as individuals faced with the prospect of losing their home garner help from those in their network. Hence during the recession in the U.S., we hypothesize that immigrants may have avoided home loss through the assistance of their network. Moreover, post the crises as the need for a down-payment became more critical in the home buying process, we hypothesize that immigrants will also leverage their networks more intensely.

Given trust is a factor that determines social capital and social capital within a network makes it possible for individuals to depend on their network during a crises period, it is reasonable to assume that immigrants who have stayed longer in the U.S. would have more social capital within the network and hence be able to leverage these networks more than recent immigrants. Moreover since naturalized immigrants have on average spend more time in the U.S. and given their permanence

\footnotetext{
${ }^{6}$ Of course a general state of economic depression like the Great Recession can reduce the effectiveness of such mutual insurance despite the existence of a large network.
} 
and less mobility, we assume they have more established networks and are able to leverage their networks more effectively. However, given these individuals are also relatively more established than non-citizens, they have more coping mechanisms than non-citizens who may depend almost entirely on their network for support during a crises. Hence the change in impact of a network based on citizenship status cannot be determined a priori. We test the effect of citizenship and recent immigrant status in our paper.

\section{Data Description}

Our sample is derived from the Current Population Survey (CPS) which is a microdata set that provides detailed information about individual persons and households. The CPS is a monthly U.S. household survey conducted jointly by the U.S. Census Bureau and the Bureau of Labor Statistics. We specifically make use of the March CPS which contains the Annual Demographic File and Income Supplement. We derive multi-stage stratified samples of the March CPS from Integrated Public use Microdata Series (IPUMS). IPUMS-CPS is an integrated set of data from 51 years (1962-2012) of the March Current Population Survey. However we only make use of data from 2000-2012 for two main reasons. First there has been significant changes in the dataset and questions asked on the survey over time. Specifically our focus is partly on immigrants birthplace and not until very recently were more immigrant's birth places defined specifically in the CPS. ${ }^{7}$ Second, our research is focused on comparing changes before and after the recession and hence restricting our period of analysis to a reasonable expanse of time before this event is useful in creating comparable periods that are likely to be free from time induced confounding factors. Given all monetary variables in IPUMS CPS are in nominal dollars and we make use of repeated crosssections over time, we adjust all monetary variables used in our analysis to constant 1999 dollars using CPI-U adjustment factor available in IPUMS (which corresponds to the 2000 CPS dollar amounts). Since the CPS mkes use

\footnotetext{
${ }^{7}$ It is important to mention that even currently, some immigrants birthplaces are still not highlighted and such immigrants are classed together by continent. The non-mention of an immigrants birthplace is especially true for small countries in Africa, South America and Asia. However all countries with significant number of immigrants are listed separately in the CPS data from 2000-2012.
} 

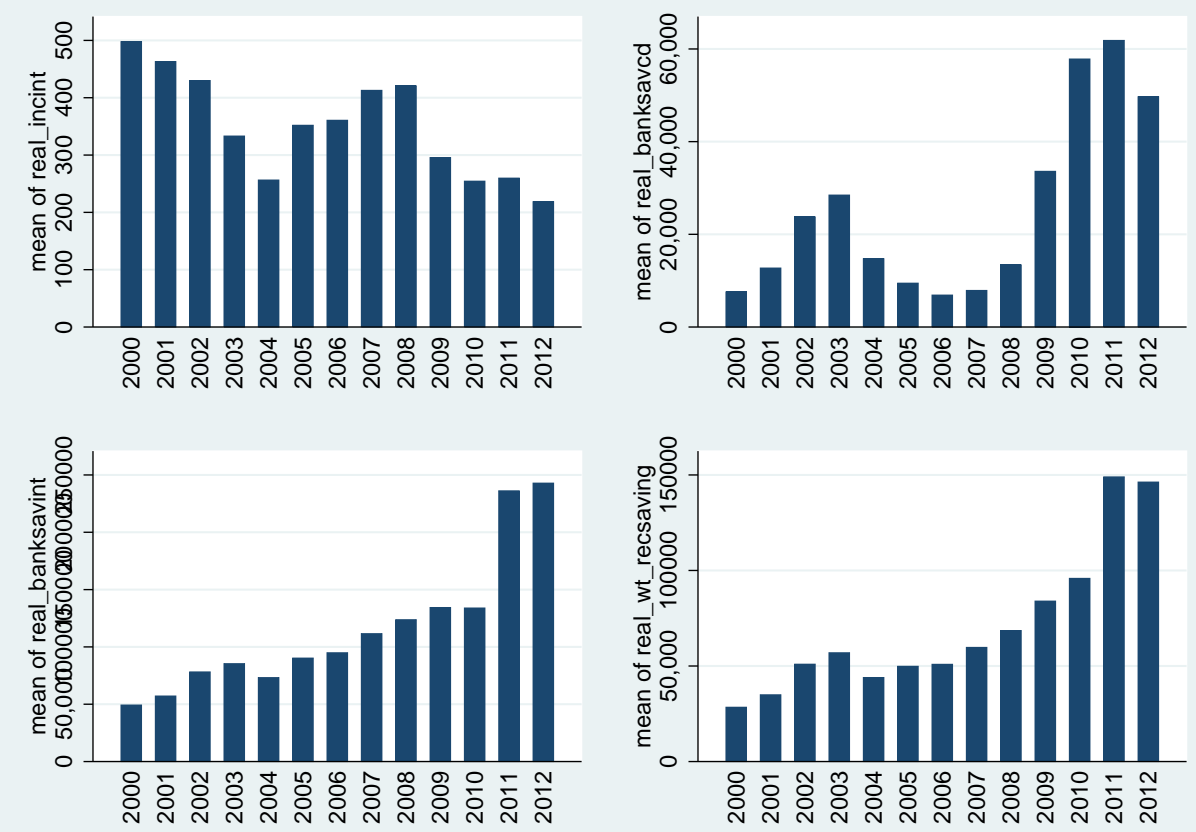

Figure 1: Changes in Savings Measures over time

of a complex stratification sampling, we include personal weights for individual in our analysis.

\subsection{Measuring Savings}

One of the variable whose effect on homeownership we are interested in is savings. We measure savings in four ways in this paper. Three of the ways we measure savings are constructed while interest income is found directly in the dataset. For most people, a significant portion of savings are done through holding money in savings accounts and certificates of deposit (CDs). Interest income as defined in IPUMS CPS captures how much pre-tax income (if any) the respondent received from interest on saving accounts, certificates of deposit, money market funds, bonds, treasury notes, IRAs, and/or other investments which paid interest. We make use of this proxy for savings because actual savings levels are not available in the CPS. Most of the surveys available like the Survey of Consumer Finances (SCF) that have information on savings do not contain a large enough sample of immigrants that can lend itself to the kind of analysis required for our questions of interest. However 
the use of interest income as a proxy for saving at a given point in time makes sense as interest income is a function of how much saving an individual has and hence a high degree of correlation exists between interest income and savings. We are not the first to use interest income as a proxy for savings in the literature. Farlie (1999) and Belton and Uwaifo Oyelere (2008) both use interest income and dividend income as proxies for savings. Although interest income is a good proxy for savings at a point in time, when comparing groups over time, using interest income to capture saving can lead to problematic inference. This is because a decline in interest income over time does not imply a decline in savings and could simply be because of a decline in the interest rate charged. Given the significant fall in interest rates and CD rates over the 2000-2010 period, more especially since 2007, we are concerned about potential inferences on changes in saving over time from trends in interest income. The first graph in Figure 1 highlights the changes in mean yearly real interest income over our data period. Notice that interest income has a lot more variation over time than our constructed measures of savings and has declined from 2007 onwards. This decline in interest income does not imply a decline in savings. Specifically, there is evidence in the past literature that suggests that savings increased during the financial crises and onwards. Hence having measures that capture the noted trend in savings is useful.

As a way to deal with the limitations of interest income as a proxy for savings, we attempt to recover savings using the information on interest income. We recover savings in two main ways. First we obtain data on average annual rates for the 6 Month CD from 2000-2012. ${ }^{8}$. We then assume that the yearly interest income found in our CPS data for individuals is obtained solely from CD account. Using the information on the historic average annual rates during each year, we estimate the yearly size of savings that can lead to the interest income levels noted in the data for each individual. ${ }^{9}$ The second way we recover savings is similar to the first. In this case we recover savings levels assuming interest income observed in our data is derived solely from basic savings accounts. We obtain yearly average bank savings rates from "Bankrate, Inc." online and as with CDs described above, we recover the level of savings that could yield the interest income levels noted

\footnotetext{
${ }^{8}$ Data is obtained from forecastchart.com

${ }^{9}$ Compound interest is calculated across institutions in different ways: daily, monthly, quarterly or yearly. In recovering yearly savings level, we take the most straightforward approach assuming compounding yearly.
} 
in our data. Given most individuals' interest income is likely a combination of at least these two sources of interest income, we create our last proxy for savings as a weighted average of the savings level recovered assuming CD rates and the savings levels recovered assuming bank savings rates. While we know that these measures are rough estimates given individuals may have obtained their annual interest income levels via more than one or two channels, we are of the opinion that this recovered savings levels form a good proxy for actual savings levels. ${ }^{10}$ We illustrate trends in each of these recovered savings measures in the 3 later graphs of figure 1. Notice that unlike interest income (first graph) that declined from 2007 and onwards, our three measures of savings show increase in savings during this period which is more consistent with trends in savings rates from data from the U.S. bureau of economic analysis and the U.S federal reserve. ${ }^{11}$ Moreover, beyond individuals having higher savings rate during this period, bank savings levels were further elevated as individuals moved money out of the stock market to much safer financial options like bank saving accounts and CDs. This could partly explain the elevated savings levels illustrated in figure 1 using our three recovered savings measures. ${ }^{12}$

\section{$5 \quad$ Preliminary Descriptive Statistics}

We present some summary statistics using tables and graphs that serve in part as a motivation for our research and the kind of questions we hope to answer in this paper. Table 2 summarizes some key variables in our study and gives the sample sizes, means and standard deviation across immigrants based on immigrants' birthplace continent. The seven main birth continent categories we divide into are as follows: those born in North America but not U.S. (henceforth NANU), those born in Central America and the Caribbeans(henceforth CAC) (this group also includes those born Mexico), those

\footnotetext{
${ }^{10}$ It is important to mention that our recovered savings measures are in real terms using the base year of 1999. Given our data spans 13 years, all our monetary variables are converted to real terms using the CPI index. The base year is 1999 .

${ }^{11}$ data from the U.S. bureau of economic analysis suggests that personal savings rates that were typically below $4 \%$ before the recession rose to over $8 \%$ in 2008 and by late 2012 was a little over $6 \%$.

${ }^{12}$ Our savings measures are just estimates and could be somewhat inflated especially the estimate using bank interest rates. Recall that interest income data is from multiple sources as defined above and our measures are based on just the two common sources of interest income.
} 


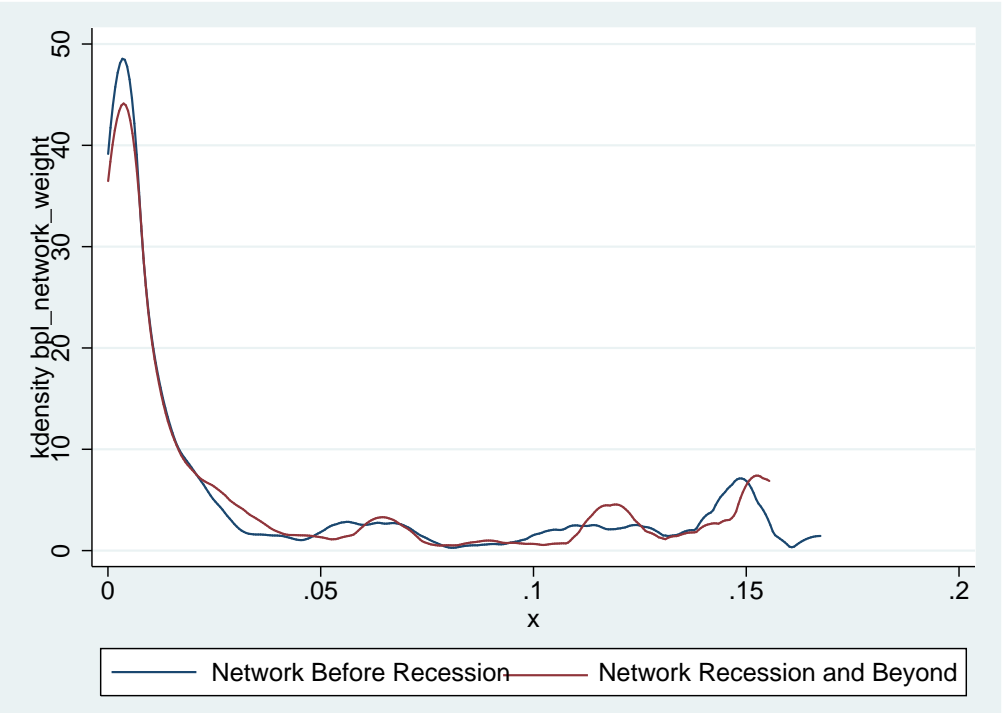

Figure 2: Birth place network before the Recession and Beyond

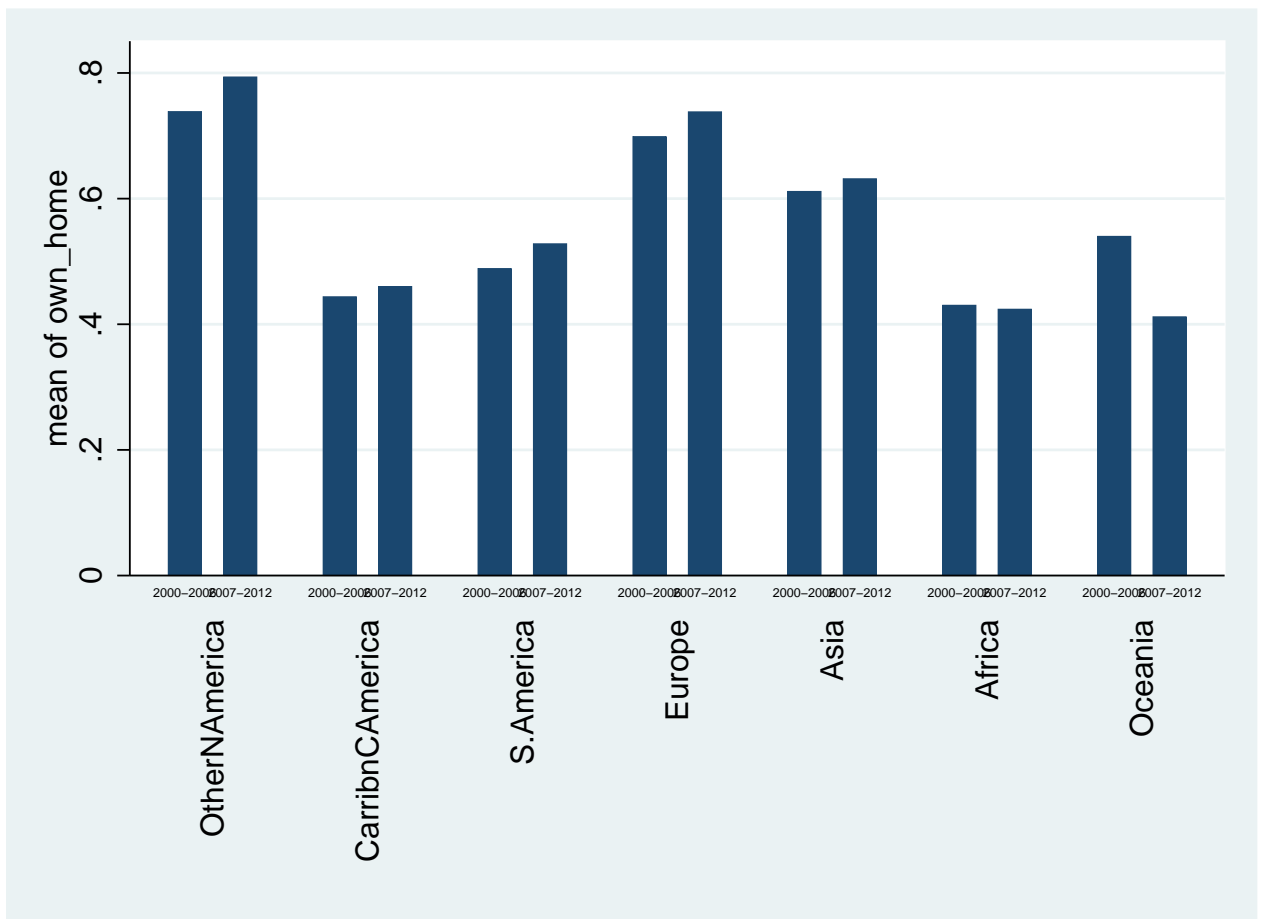

Figure 3: Changes in Homeownership by birthplace continent over time 
born in South America, Europe, Asia, Africa, those born in Australia and New Zealand which we refer to as Oceania. ${ }^{13}$ There are several observations from Table 2 that provide added motivation for why heterogenous impacts on homeownership across immigrants is likely. First we find that the share of immigrants from a birthplace who are naturalized is significantly higher for Europeans and Asians than immigrants from South America or Africa. Quite noticeable is the lowest share of naturalized immigrants from CAC which is driven primarily by the large illegal/undocumented immigrant population from Mexico in the last two decades. The presence of a strong network can serve to attenuate an immigrant's vulnerability especially during a period of crises like the recession. Table 2 suggests significant heterogeneity in network across immigrants based on birthplace.

Figure 2 highlights the change in the density distribution of the birth place network variable before the recession and since the recession. This figure suggests two things. First, there is a wide level of variation in the birthplace networks immigrants face. Second, the distribution of birthplace networks for immigrants has not changed significantly over the two time periods we consider which suggests no significant demographic shift among immigrants during this period. As a robustness check on the lack of change in distribution of networks over the periods we consider, we also graph the density function of birthplace network for the two periods separately in the four states with the highest immigrant population (figure not included in paper) to see if the distribution of networks changed between the two period in each of these states but noted that while distributions differed across these four states, changes in the distribution over the two time periods we consider was minimal in each state as the overall trend.

Age can increase the probability of homeownership and can play a role in reducing an individuals vulnerability to homeownership loss and so does the years in the U.S. Table 2 shows that on average immigrants from CAC, Africa and Oceania are younger than immigrants from elsewhere. Table 2 also highlights significant heterogeneity in the length of stay of immigrant across birthplace with immigrants from Europe and other countries in North America having on average length of stay in

\footnotetext{
${ }^{13}$ The data also included respondents who do not indicate their country of birth hence we cannot assign them to continent groupings. We include these individuals in a category called others which we do not eliminate from our sample but do not report any results focused solely on this group.
} 

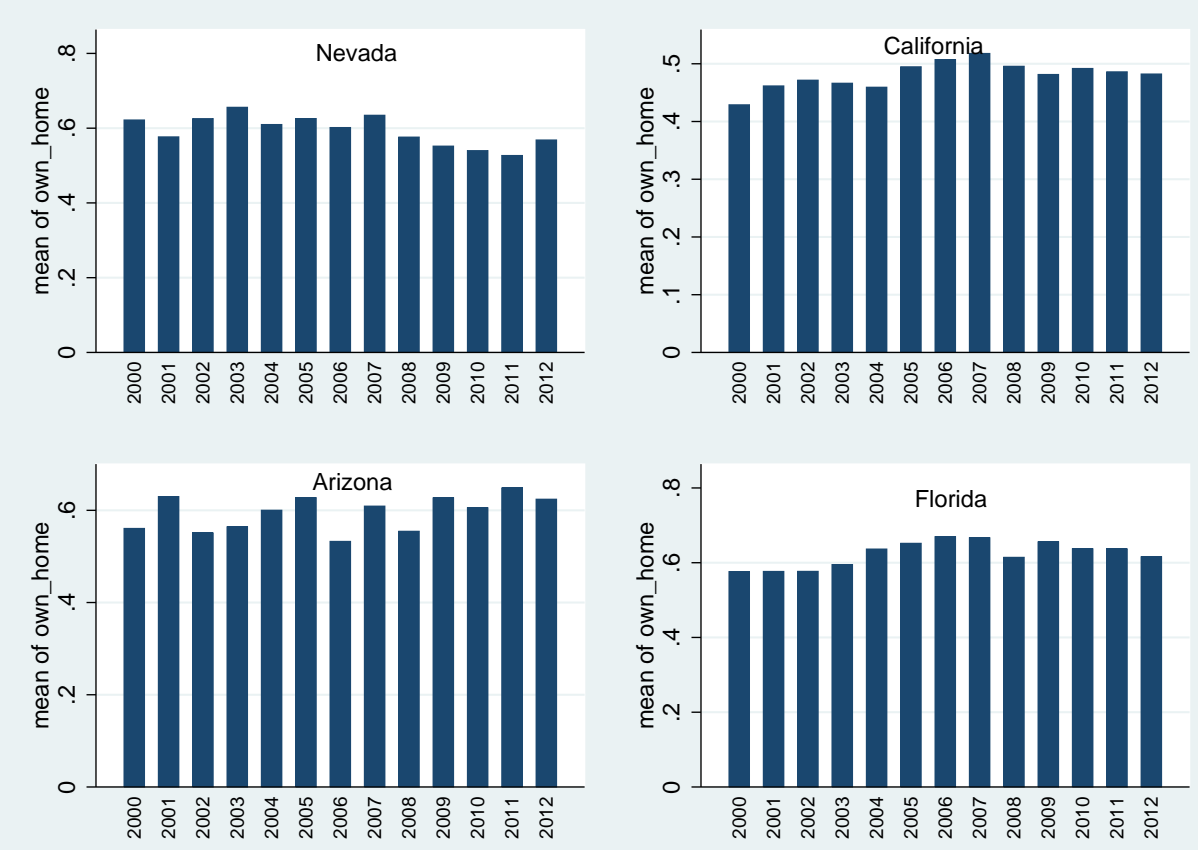

Figure 4: Changes in Homeownership over Time across select States

the U.S above 20 while immigrants from other regions have on average less than 20 years. If length of stay reduces vulnerability especially during an economic crises, and hence increases homeownership or reduces loss of homeownership, then we expect immigrants from regions with lower mean length of stay to be more vulnerable. We also find significant heterogeneity in savings across various immigrant groups with Europeans, NANU and Asians having higher savings than other regions.

Figure 3 shows mean homeownership by birthplace for immigrants pre recession and onwards. These results also suggest heterogeneity across groups in the changes in homeownership over time. Specifically, while there was a decline in homeownership for immigrants from Oceania and Africa we see no decline for immigrants from the other regions. This increase in homeownership for these immigrant groups during the recession is consistent with the patterns observed in Painter and $\mathrm{Yu}$ (2012) using 2009 data. The heterogeneity in homeownership rates over time is not only present across birthplace, differences across states in patterns over time also exists. Figure 4 captures these differences across four states that were on average more affected by the housing crises: Nevada, 

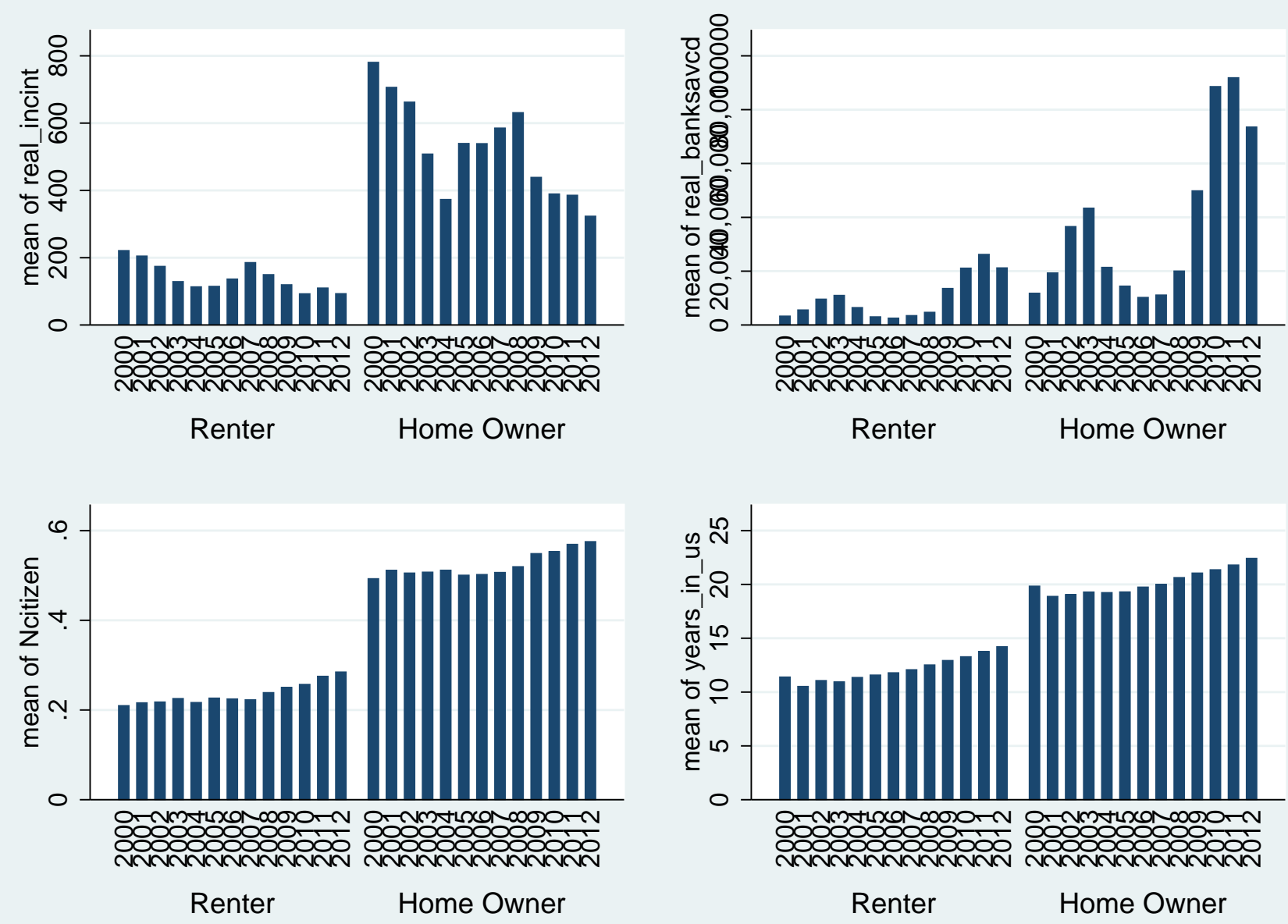

Figure 5: Differences between Owners and Renters

California, Arizona and Florida. The homeownership trends for immigrants across these four states differ. Immigrants experienced a decline in homeownership in all 4 states between 2007 and 2008 but the level of decline and trend in change since the recession differed across these states. ${ }^{14}$

Differences in savings pattern is one potential explanation for the heterogeneity in homeownership rates over time. Mody et al. (2012) have estimated that there was a sharp increase in precautionary savings around the globe during the great recession and we notice this trend in the average savings across all immigrant groups in Table 3 . Table 3 captures savings by birth place continent for both

\footnotetext{
${ }^{14}$ The heterogeneity in trends across states is one reason why we include state fixed effects in our estimation analysis summarized in Table 5-10.
} 
periods. The savings proxies used in this table are recovered savings assuming CD rates and interest income. One can estimate the change in savings for each group between the pre recession period and 2007-2012. Finding this simple difference by birthplace continent highlights significant heterogeneity in the change in savings over this period across groups. It is worth noting that immigrants from NANU exhibited the highest increases in savings over this period and as noted earlier also exhibited no decline in homeownership rates. In contrast immigrants from CAC, Oceania and Africa exhibited the lowest increase in savings levels over this period and also exhibited the greatest decline in homeownership. While we do not infer anything causal from this trend, controlling for birthplace continent in our analysis is necessary.
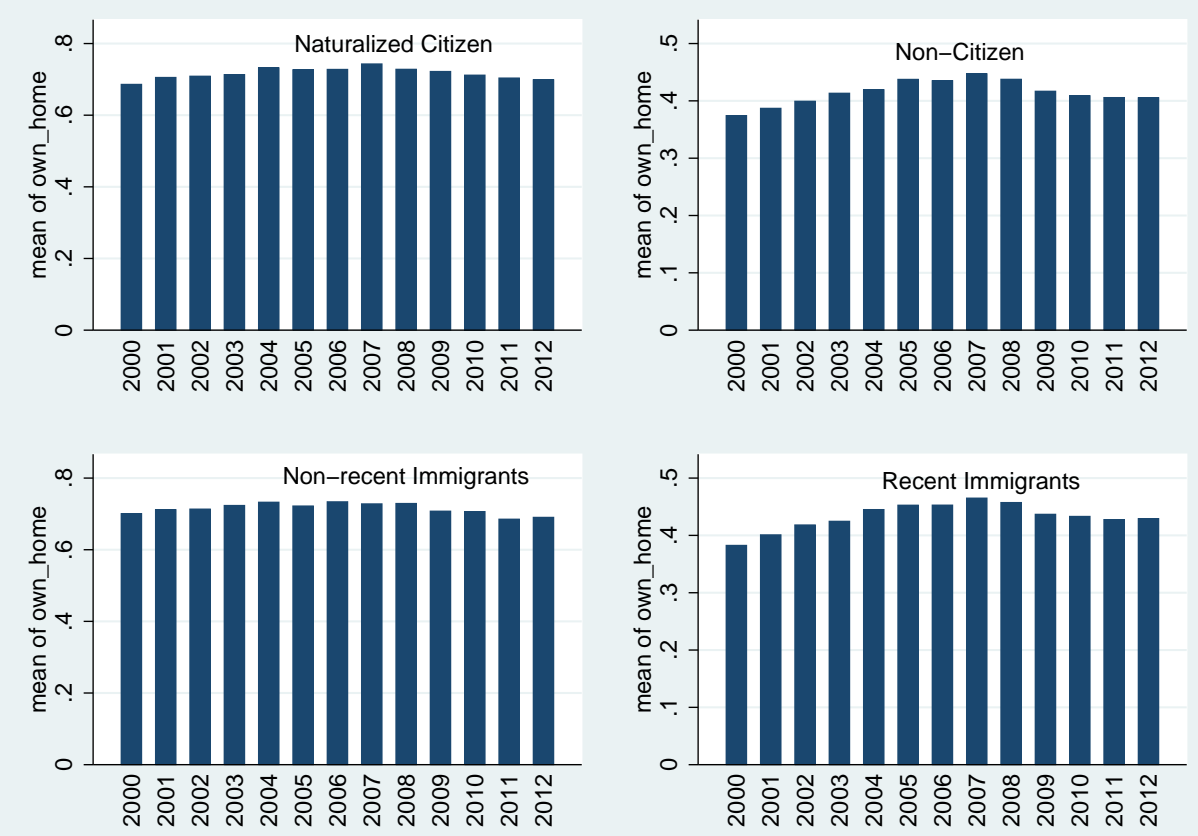

Figure 6: Changes in Homeownership by Citizenship Status and Length of Stay

Table 4 explores how these changes in savings differ across age groups. The results suggest that savings increased for all groups. In terms of difference between the two periods, we note an increasing trend based on age cohort. Specially the largest increase occurred among the oldest population and the smallest increase was noted among the cohort 35 and younger. As noted above, increases in 
savings are consistent with the wider literature that shows significant increases in savings during the recession and subsequently.
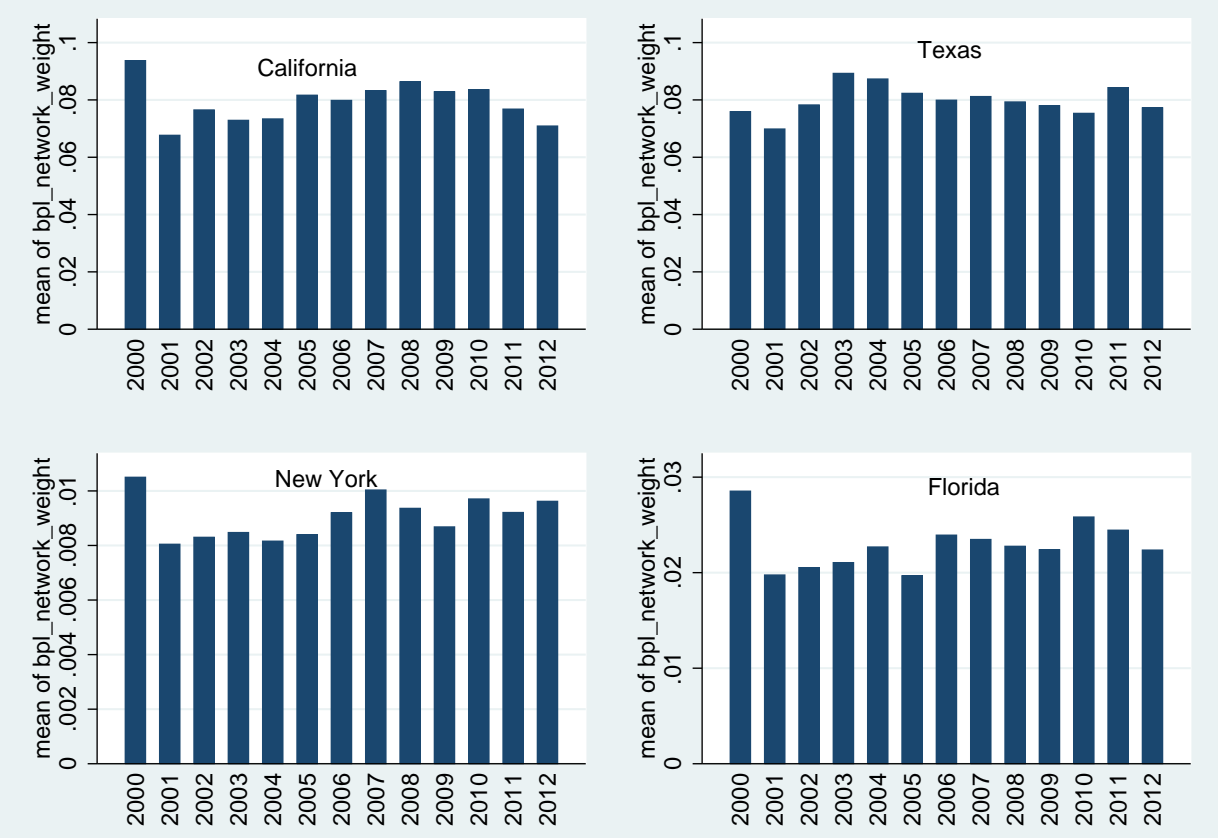

Figure 7: Changes in birth Place network in select States

The need to control for certain variables when estimating differences across groups in homeownership probabilities is highlighted in figure 5-7. Figure 5 illustrates the differences between homeowners and renters on four of the factors we consider in this paper in our empirical analysis. First this figure suggests immigrants who own homes are more wealthy than those who do not, have stayed a longer time in the U.S and are also more likely to be U.S citizens. Figure 6 highlights the trends in homeownership by citizenship status and recent immigrant status over time. We define recent immigrant as one who at the time of the survey had spent less than 20 years in the U.S. Figure 6 suggests a higher decline in homeownership rates from the recession onward for non-citizens compared to citizens but similar decline for recent immigrants. We consider more carefully these kinds of differences in a regression setting later on in the paper. The role of networks during the 
recession and onwards is one we pay close attention to in this paper given its potential importance in attenuating homeownership vulnerability during crises periods. Figure 7 highlights time trends in the size of individuals' birthplace network across four states that have the highest size of immigrants: Texas, California, New York and Florida. This figure provides evidence of heterogeneity in network size across states over time. Moreover the average size of the network in Florida is much smaller than the size in the other three states which are more similar. Of interest to us is to what extent these networks can affect the probability that an individual owns a home and to what extent this effect differs across citizenship status, recent immigrant status and birthplace. In the next section we highlight our empirical strategy for estimating these effects.

\section{Empirical Model}

To examine the role of savings, birth place networks and years in the U.S. on the probability of homeownership for immigrants before and during and after the Great Recession, we estimate the following difference -in- difference (DID) probit model and derive the marginal effects for our variables of interest.

$\operatorname{Pr}\left(O_{i s j}=1\right)=\beta_{1} X_{i}+\beta_{2} S_{i}+\beta_{3} N_{s j}+\delta_{1, s}+\gamma_{1, b r}+\psi_{1, t}+R_{i}\left(\beta_{4} X_{i}+\beta_{5} S_{i}+\beta_{6} N_{s j}+\delta_{2, s}+\gamma_{2, b r}+\psi_{2, t}\right)+\varepsilon_{i s b r}$

Where $O_{i s j}$ is the decision to own a home by the immigrant $i$ living in state $s$ from a country $j$. $O_{i s j}$ is a dummy variable and it takes the value of 1 if an individual owns a home and 0 otherwise. $^{15}$ Individual controls are incorporated in matrix $X_{i}$ and include educational attainment, sex of the household, age, family size, years in the U.S., citizenship status. We also control for marital status and employment status as well as the log of the household real income and in some specifications we include total income. Our savings measure at the household level are included in $S_{i}$ and we measure savings in four different ways as highlighted in our data description. Our network variable

\footnotetext{
${ }^{15}$ It is also important to note that the CPS data does not have information on whether this is an immigrants' first home or not. Hence, we are not able to distinguish between the effect of savings and networks on buying a first home or sustaining existing homes.
} 
is included in $N$ and is measured by the share of the sample living in the immigrants state $s$ from her home country $j$. A full set of birth country region effects $\left(\gamma_{b r}\right)$, year fixed effects $\left(\psi_{t}\right)$ and state level effects $\left(\delta_{s}\right)$ are also included. We also include metro area dummies. $R_{i}$ is our treatment or recession dummy that takes the value 1 for the years 2007 - 2012. We estimate this probit model and given the difficulty in interpreting probit estimates directly, we calculate marginal effects.

The marginal effect estimate of $\beta_{3}$ captures the effect of an increase in birthplace network before the recession on the probability of homeownership and $\beta_{6}$ captures the change in the effect of networks on homeownership in the GRA period. Based on our conceptual framework, we expect $\beta_{6}>0$. Similarly $\beta_{5}$ captures the change in the effect of savings on homeownership in the GRA period and the vector $\beta_{4}$ captures the change in the effect of citizenship status and the change in the effect of years in the U.S. post recession.

To examine the effect of how birthplace networks vary with citizenship and years in the U.S., and birth place regions we modify the model given by equation (1) by including further interactions. First we include interactions between birthplace network and citizenship status, and a triple interaction between recession, birthplace network and citizenship status. Next we include interactions between birthplace network and recent immigrant status, and a triple interaction between recession, birthplace network and recent immigrant status. ${ }^{16}$. Finally, we estimate the model again including interactions between birthplace network and birth regions, and a triple interaction between recession, birthplace network and birth regions. For this analysis, we focus on three birth regions we construct. First is European descent where we merge immigrants from Oceania, Europe and NANU into one group given similarity in ancestry and level of development for these birthplace regions. Second Latin America where we combine immigrants from South America with immigrants from CAC. Our final region is Asia. The need to consider these broader classifications of birth place regions is due to our attempt to estimate differential network effects across birth regions. However given our identification strategy requires our inclusion of state fixed effects and our network variable is constructed at the state level, without broader classifications we will be attempting to identify

\footnotetext{
${ }^{16}$ As mentioned earlier on in the paper, we identify recent immigrants if at the time of survey immigrant had been in the U.S less than twenty years.
} 
effects amidst limited variation in birthplace network which could possibly lead to bias and inconsistent estimates. It is important to mention that for this analysis of differential network effects across regions, we drop observations from Africa. Our rationale for doing this is that immigrants from Africa cannot be analysed separately because the sample size for this region is small and there is limited variation in the birthplace network variable within this region. As mentioned above, attempting to identifying effects amidst limited variation is not useful. The possible alternative is to class the observations from Africa within one of the broader groups mentioned above. However given significant differences in ancestry, historical institutional exposure and current levels of development between these other groups and Africa, classing immigrant from Africa with any of these three regions does not seem appropriate.

It is worth noting that there is a possibility that there are some unobserved factors that are correlated with networks from country $j$ in a state $s$ as well as with the chance of homeownership by immigrant $i$ from country $j$ in state $s$. For instance, many immigrants from China might settle in California not only because of the past network effect but due to the higher overall chance of homeownership for an individual migrant in California. We minimize this potential source of endogeneity by including state fixed effects in our model. Hence effects are identified eliminating unobservable across states that may be connected to network size and homeownership. Also to mitigate other potential bias in our main variables of interest, we include in our model extensive geographical controls. We include birth continent dummies, year fixed effects and controls for living in a metro area. There is a possibility that second homeowners have higher networks since homeownership often leads to a better community building and possibly more networks. This could potentially lead to reverse causality from networks to homeownership. In CPS we cannot distinguish whether the immigrant is a previous homeowner or it is their first home. However, we worry less about this issue because our network variable is based on concentration of immigrants from an individual's birth country at the state level which is independent of an individual's second homeownership. More generally, although our inclusion of state fixed effects and other aforementioned controls likely eliminates potential bias 
in the estimate of the birthplace network variable, we cannot completely rule out the possibility of unobservables within a state correlated with homeownership and birthplace networks within that state. Moreover, our main focus in this paper is not on deriving a consistent estimate of birthplace network but rather on obtaining a consistent estimate of the change in the impact of the factors we are interested in over the two time periods (BGR and GRA), which is possible as long as any residual potential bias in estimates is invariant between these two periods.

\section{$7 \quad$ Results}

Table 5 gives the results from estimating a model of homeownership before we bring in our key savings and network variable. We find that household income, wages and total income all have a higher effect on homeownership during and after the recession. However, we find a slight decline in the role of years in the U.S in predicting homeownership over the two time periods. Although the effect increases after we account for income or wages Table 5 also shows that immigrants' U.S. citizenship has a role to play in homeownership. Immigrants who are naturalized citizen have a higher chance of homeownership than non-citizens. We further find that compared to non citizens, citizens were further able to increase their likelihood of homeownership or sustain their current homeownership during 2007-2012. However, we are more cautious with this result given the interaction coefficient is significant only at the $10 \%$ level and is insignificant if we control for income using wages or total income. The other variables are all significant and have the usual sign. Older household head, being a female and higher educational attainment all increase the chances of homeownership in the U.S. Moreover, the effect of these variables stay more or less the same during pre-recession and during 2007 - 2012 period. Interestingly we find a decline in the marginal effect of family size on homeownership during 2007 - 2012 compared to the pre recession period possibly due to additional family members moving in with other household members. For columns (3) - (5) we note that after controlling for the household income variables, the marginal effect of the family size falls by 1 percentage point in the GRA period.

In Table 6 we add our household savings measures. Columns (1) uses interest income as a control, 
column (2) makes use of recovered savings using CD. In column(3) we use the recovered saving measure from bank interest and column (4) uses the measure that captures the weighted average of the two measures. Table 6 suggests that savings increase the probability of homeownership. However the change in the effect over the two periods we consider is negative. For example the effect of savings using interest income declined by 0.001 using our alternative measures apart from savings recovered via $\mathrm{CD}$ which showed a decline of 0.002. This results suggest that as expected immigrants with higher savings still have a higher chance of homeownership. However the decline in the effect suggests that savings are used for more precautionary motives and possibly for future home buying and hence the predictive effect of savings falls during the 2007 - 2012 period. All the other variables have similar effect as Table 5 .

Table 7 gives the results from our full model where we examine the effect of birthplace networks after controlling for household savings and other housing determinants. We find that birthplace networks have a significant positive effect on homeownership and this effect further increases significantly in the GRA period. This increased reliance on networks holds after controlling for savings measured in all ways. On an average there is a 22 percentage points increase in the marginal effect of an immigrants' home country network on their homeownership. Including all the controls and the savings effect we find that networks are significant for immigrant probability of homeownership and they play a more critical role since the Great Recession began in 2007. Given the increased effect of birthplace networks during 2007 - 2012, we can conclude that immigrants relied on their networks as a form of insurance during the crises period to sustain existing homes or as an assistance in new home purchases.

Our finding birthplace networks affect homeownership and the impact has increased substantially in the GRA period is a new and significant result. To further confirm the validity of this result, we conduct a further robustness check to see if our results are sensitive to year 2007 being included in our recession years. Our rationale for doing this is linked with the fact that the recession began in the last quarter of 2007. Hence technically speaking most of 2007 was prior to the recession. To test if our results are sensitive to where 2007 is placed, we redo the econometric analysis above including 
observations from 2007 in the pre recession period and recreate our dummy for recession covering 2008-2012 versus 2007-2012. These results provide estimates similar to those in Table 7. Our results are not sensitive to the inclusion of 2007 in the recession period as we do not find a statistically significant change in our variables of interest when observations from 2007 are moved to the BGR period..$^{17}$

Table 8 provides a robustness check of these results estimated using only individuals who are age 35 and above during the year of observation. The rationale for this is from our descriptive section where heterogeneity in the changes in savings from the onset of the recession by age cohort is noted. More immigrants 35 and younger may be recent immigrants and hence it might be interesting to see the differential impact of networks if only those above 35 are considered. Our results suggest that the decline in the impact of savings is similar to Table 7, indicating that there is no change for the impact of interest income when we exclude the younger population. More importantly the results in Table 8 suggests that the impact of networks on homeownership is stronger for those who are older but the change in the effect of these networks is smaller than when we include the younger population (approximately 25\%) in Table 7. This results suggest that post the recession, networks became more important for younger immigrants. Hence, although birthplace networks still has a stronger effect on the probability of homeownership for older age cohorts, the gap in effect between the young and older age cohorts seems to have shrunk during the recession. Given older age cohorts have many sources of buffer (savings) or coping mechanisms during a crises while younger age cohorts do not, when there is a crises, these younger immigrants may have to fall back more on their network which could explain the increased role of networks for these individuals during the 2007-2012 period, despite a lower impact of networks on homeownership for this cohort in general.

Table 9 and 10 summarize the results that address our third question. In Table 9 we present the results focused on the question of heterogenous impacts of networks based on citizenship status and recent immigrant status. The result for citizenship and network interaction is summarized in panel A while panel B has the results of the relevant coefficients for the interaction between network

\footnotetext{
${ }^{17}$ These results are not included in the paper but are available on request from the authors.
} 
and recent immigrant status. The results suggest that birthplace networks are more important for immigrants who are citizens and immigrant who are not recent(arrived in the country before twenty years). We do not find evidence for heterogeneity in the change in the effect of birthplace networks across citizenship status and recent immigrant status. It is also important to mention that while the effect of being a citizen on homeownership appears to have increase slightly in the GRA period, there is no change in the effect of being a recent immigrant on homeownership between both periods. These findings support the view that immigrant who are citizens or have been in the U.S for a while

might have more information about financial institutions and the way the housing market works in the U.S. and are better able to leverage their networks for their homeownership outcomes.

Table 10 shows the results from the analysis where we interact birthplace networks with the birth region and recession. We find that Asians and the European decent group have significantly higher homeownership than Latin Americans and they were further able to increase their homeownership compared to Latin Americans in the GRA period. We also find that the effect of birthplace networks on homeownership is much stronger for Asians and those with Europeans decent in comparison to those with Latin American decent. We do not find any evidence of heterogeneity among these birth regions in the change in the role of birthplace networks in the GRA period. Our results are consistent with our prior argument that immigrants from countries with very high immigrant populations may not feel the need to have social birth country clubs or associations and hence may not be able to leverage their birthplace network as well as other smaller close knit groups when necessary. We are more cautious with interpreting the results in Table 10 because of further diversity even within our constructed birth regions.

\section{Conclusion and Implications}

In this paper we have considered three questions. First, has the impact of immigrants' savings, years in the U.S., and U.S. citizenship on homeownership probability changed from the recession onward? Second, what is the role of birthplace networks before the recession on the probability of 
owning a home and has that impact changed from 2007-2012? Third to what extent does the impact of birthplace networks exhibit heterogeneity based on citizenship status, being a recent immigrants and region of birth and has the recession changed this impact differently across these groups? We find that while the impact of most factors that predict homeownership remain virtually the same over these time periods, the role of of savings and years in the U.S. appears to have decreased while the role of citizenship appears to have increased but this change is not robust to all specifications.

After accounting for savings and other housing determinants, we find that birthplace networks are important for homeownership and their importance in predicting homeownership has increased since 2007. While we find evidence of heterogeneity in the impact of birthplace networks on homeownership based on citizenship status, recent immigrant status and birthplace region, we do not note any change in this heterogeneity since 2007 compared to earlier years.

In conclusion, our results suggest that immigrants may not have experienced a significant decline in homeownership rates during the recession because they were able to leverage their networks with home country compatriots in the U.S. to increase their chances of homeownership or to sustain their current homeownership. This role of networks in assisting immigrants seems to be more important if immigrants spend more time in the U.S. and are citizens. Given that birthplace networks have a significant impact on homeownership and social networks are a part of social capital, then our results may also suggest that social capital makes a difference for immigrants in buying their first home or in sustaining homeownership during a crises and afterwards.

\section{References}

[1] Adsera A. and B. Chiswick 2007. "Are there gender and country of origin differences in immigrant labor market outcomes across European destinations?, Journal of Population Economics, 20: $495-526$.

[2] Alba, Richard D. and John R. Logan 1992. "Assimilation and Stratification in the Homeownership Patetrns of Racial and Ethnic Groups," International Migration Review, 26(4): 1314-1341. 
[3] Allen R. 2009. "The Unraveling of the American Dream", Working paper, Humphrey Institute of Public Affairs, University of Minnesota.

[4] Alesina A. and P. Giuliano, 2013. "Family Ties," NBER Working Papers 18966, National Bureau of Economic Research, Inc.

[5] Avery R., Bevoort K., Canner G., 2008. The 2007 HMDA Data” Federal Reserve Bank Bulletin, December.

[6] Bair S. C. 2007. The Case for Loan Modification. Washington DC: Federal Deposit Insurance Corporation.

[7] Bocian, D., Ernst, K., Li W., 2008. Race, Ethnicity and Subprime Home Loan Pricing, Journal of Economics and Business, 60, 110-124.

[8] Bohn S. and S. Pearlman 2013. "Ethnic Concentration and Bank Use in Immigrant Communities," Southern Economic Journal 79(4): 864-885.

[9] Borjas, George J. 2002. "Homeownership in the Immigrant Population" Journal of Urban Economics, 52: 448-476.

[10] Boyd, M. 1989. "Family and Personal Networks in International Migration: Recent Developments and New Agendas," International Migration Review, 23(3).

[11] Bauer, Thomas K., Cobb-Clark, Deborah A., Hildebrand, Vincent A. and Sinning, Mathias G. 2011. "A Comparative Analysis of the Nativity Wealth Gap," Economic Inquiry, 49(4):9891007.

[12] Belton, W., Uwaifo Oyelere, R, 2008. "The Racial Saving Gap Enigma: Unraveling the Role of Institutions," IZA Discussion Papers 3545, Institute for the Study of Labor (IZA).

[13] Chatterjee, Swarn 2009. "Do Immigrants Have Lower participation Rates in U.S. Finnacial Markets," International Journal of Business and Finance Research, 3(2):1-13. 
[14] Chiswick, Barry R. and Miller, Paul W. 1996. "Ethnic Networks and Language Proficiency Among Immigrants." Journal of Population Economics, 9(1), pp. 19-35.

[15] Coulson, N. Edward. 1999. "Why Are Hispanic- and Asian-American Homeownership Rates So Low? Immigration and Other Factors" Journal of Urban Economics, 45: 209-227.

[16] Courchane, M., S., Zorn P., 2004. Subprime borrowers: mortgage transitions and outcomes, Journal of Real Estate Finance and Economics, 29, 365-392.

[17] Daglish, T. 2009. What motivates a subprime borrower to default?" Journal of Banking and Finance 33, 681-693.

[18] Di, Zhu Xiao, and Xiaodong Liu. 2007. "The importance of wealth and income in the transition to homeownership." Cityscape 2007: 137-151.

[19] Donato, Katharine M. and Ebony M. Duncan. 2011. "Migration, Social Networks, and Child Health in Mexican Families." Journal of Marriage and the Family.

[20] Donato, Katharine M., J. Trent Alexander, Donna R. Gabaccia, and Johanna Leinonen. 2011. "Variations in the Gender Composition of Immigrant Populations: How and Why They Matter." International Migration Review.

[21] Dorantes, C. A. and K. Mundra 2007. "Social Networks and Their Impact on the Employment and Earnings of Mexican Immigrants," Demography.

[22] Dorantes, C. A. and K. Mundra 2013. " Immigrant Homeownership and Immigration Status: Evidence from Spain" forthcoming in the Review of International Economics.

[23] Dymski, G., 2005. "Discrimination in the credit and housing markets: findings and challenges," in the Handbook on Discrimination (Edward Elgar), edited by William Rodgers.

[24] Ellen, I. G. and S. Dastrup 2012. "Housing and the Great Recession," Policy Brief, Russel Sage Foundation and the Stanford Center on Poverty and Inequality. 
[25] Farber, Henry S. 2012. "Unemployment in the Great Recession: Did the Housing Market Crisis Prevent the Unemployed from Moving to Take Jobs?, American Economic Review- Papers and Proceedings.

[26] Grusky D. B., B. Western, and Wimer C. 2011. The Great Recession, Russell Sage Foundation.

[27] Hilber, C. and Y. Liu 2008. "Explaining the black-white homeownership gap: The role of own wealth, parental externalities and locational preferences," Journal of Housing Economics, 17: $152-174$.

[28] Ho G., Pennington-Cross A., 2006. The impact of local predatory lending laws on the flow of subprime credit, Journal of Urban Economics, 60, 210-228.

[29] Ketkar, Suhas L and Dora, Manoj K. 2011. Wealth of Recent Immigrants to the USA, International Journal of Economic Policy in Emerging Economics, 4(4): 330-44.

[30] Kochar R., Ana G., Daniel D., 2009. Through boom and bust: minorities, immigrants and homewonership" Pew Hispanic Report.

[31] Krivo, Lauren J. "Immigrant Characteristics and Hispanic-Anglo Housing Inequality," Demography, 32(4): 599-615.

[32] Krivo, Lauren J. and Robert L. Kaufman. 2004. "Housing and Wealth Inequality: Racial-Ethnic Differences in Home Equity in the United States" Demography, 41(3): 585-605.

[33] Lax H., Michael L., Paul R., Peter Z., 2008. Subprime lending an investigation of economic efficiency, Housing Policy Debate, Fannie Mae Foundation.

[34] Li W., G. Dymski, Y Zhou, M. Chee, and C. Aldana 2002. "Chinese-American Banking and Community Development in Los Angeles County," Annals of the Association of American Geographers, 92(4):777-796.

[35] Linneman, Peter D. and Wachter, Susan, 1989. "The Impacts of Borrowing Constraints on Homeownership," American Real Estate and Urban Economics Association 17(4), pp. 389-402 
[36] Mayer C., Pence K., 2008. Subprime mortgages: What, Where and to Whom? NBER Working Paper, June 2008.

[37] Mayer C., Pence K., Sherlur S., 2009. The rise of mortgage defaults, Journal of Economic perspectives, 23(1), 27-50.

[38] Diaz McConnell, Eileen and Enrico Marcelli. 2007. "Buying into the American Dream? Mexican Immigrants, Legal Status, and Homeownership in Los Angeles Country" Social Science Quarterly, 88(1): 199-221.

[39] Diaz McConnell, Eileen and Ilana Redstone Akresh. 2008. "Through the Front Door: The Housing Outcomes of New Lawful Immigrants" International Migration Review, 42(1): 134162.

[40] Diaz McConnell, Eileen and Ilana Redstone Akresch. 2010. "Housing Cost Burden and New Lawful Immigrants in the United States" Population Research and Policy Review, 29(2): 143171.

[41] Mantruk, K., Lindblad, M. and Q. Roberto 2010. "Friends and Neighbors: Homeownership and Social Capital among Low- to Moderate-Income Families," Journal of Urban Affairs, 32(4), pp.471-88.

[42] Mayer, C. J. and Engelhardt, G. V. 1996. "Gifts, Down Payments, and Housing Affordability," Journal of Housing Research, 7(1), pp. 59-77.

[43] Mody, A., F. Ohnsorge and D. Sandri. 2012. "Precautionary Savings in the Great Recession", IMF Working Paper 12/42.

[44] Munshi, Kaivan 2003. "Networks in the Modern Economy: Mexican Migrants in the U. S. Labor Market," The Quarterly Journal of Economics, 549-599.

[45] Mundra, K. 2013. "Minority and Immigrant Homeownership Experience: Evidence from the 2009 American Housing Survey," IZA Discussion Paper7131. 
[46] Myers, D. and J. Pitkin 2013. "Immigrant Contributions to the Housing Demand in the United States: A Comparison of Recent Decades and Projections to 2020 for the States and Nation" Research Institute for Housing America Special Report.

[47] Nothaft, F., Perry V., 2002. Do mortgage rates vary by neighborhood? implications for loan pricing and redlining, Journal of Housing Economics, 11:244-265.

[48] Osili, Una O. and Anna Paulson. 2007. "Immigrants' Access to Financial Services and Asset Accumulation," in Access, Assets, and Poverty, ed. by Rebecca Blank and Michael Barr.

[49] Osili, Una O. and Anna Paulson. 2008. "Symposium in Access to Finnace: What can we Learn about Financial Access from U.S. Immigrants Home Country Institutions and Immigrant Beliefs" World Bank Economic Review, 22(3):431-55.

[50] Osili, Una O. and Anna Paulson. 2009. "Bank Crises and Investor Confidence" Working Paper CES 09-02.

[51] Owens, Ann and Sampson Robert. 2013 "Community Well-Being and the Great Recession" published in Recession Trends. Retrived on June 10th 2013 from http://www.stanford.edu/group/recessiontrends/cgi-bin/web/.

[52] Paulson Anna and Sherrie L. W. Rhine 2008. "Financial Assimilation of an Immigrant Group: Evidence on the use of Checking and Savings Account," Journal of Family and Economic Issues 29: $264-78$.

[53] Painter Gary and Zhou Yu. 2012. Caught in the Housing Bubble Immigrants' housing outcomes in traditional gateways and newly emerging destinations. Center for the study of immigrant integration Paper.

[54] Renaurt, E. 2004. An overview of the predatory mortgage lending process" Housing Policy Debate, Fannie Mae Foundation. 
[55] Rhine, Sherrie L. W., William H. Greene, and Maude Toussaint-Comeau 2006. "The Importance of Check-Cashing Business to the Unbanked: racial/Ethnic Differences", Review of Economics and Statistics 88: 146-157.

[56] Ruggles Steven, J. Trent Alexander, Katie Genadek, Ronald Goeken, Matthew B. Schroeder, and Matthew Sobek. Integrated Public Use Microdata Series: Version 5.0 [Machine-readable database]. Minneapolis: University of Minnesota, 2010.

[57] Shanmuganathan P., M. Stone, and B. Foss 2004. "Ethnic Banking in the USA," Journal of Financial Services Marketing, 8(4): 388-400.

[58] Simmons, P. 2001. Changes in minority homeownership during the 1990s, Fannie Mae Foundation Census, Note 07.

[59] Toussaint-Comeau, Maude and Sherrie L. W. Rhine. 2004. "Tenure Choice with Location Selection: The Case of Hispanic Neighborhoods in Chicago" Contemporary Economic Policy, 22(1): 95-110.

[60] Yamamura, Eiji 2011. "How Do Neighbors Influence Investment in Social Capital? Homeownership and Length of Residence" International Advances in Economic Research, 17(4), pp. 451-64 011

[61] Yu, Zhou 2006. "A Different Path to Homeownership: The Case of taiwaneses Immigrants in Los Angeles" Housing Studies, 21(4): 555-579 
Table 2: Summary Statistics by Birth Place Continent

\begin{tabular}{|c|c|c|c|c|c|c|c|}
\hline & $\begin{array}{l}\text { Other North } \\
\text { America }\end{array}$ & $\begin{array}{c}\text { Central America/ } \\
\text { Caribbeans }\end{array}$ & $\begin{array}{c}\text { South } \\
\text { America }\end{array}$ & Europe & Asia & Africa & Oceania \\
\hline $\begin{array}{l}\text { Years in } \\
\text { the U.S }\end{array}$ & $\begin{array}{c}24.24 \\
(17.93)\end{array}$ & $\begin{array}{c}15.75 \\
(11.59)\end{array}$ & $\begin{array}{c}15.06 \\
(11.71)\end{array}$ & $\begin{array}{c}22.99 \\
(16.97)\end{array}$ & $\begin{array}{c}15.95 \\
(11.72)\end{array}$ & $\begin{array}{c}11.90 \\
(10.26)\end{array}$ & $\begin{array}{c}15.16 \\
(12.92)\end{array}$ \\
\hline $\mathrm{N}$ & 6207 & 153046 & 21490 & 33038 & 78195 & 11442 & 2032 \\
\hline Home & 0.762 & 0.452 & 0.508 & 0.717 & 0.623 & 0.446 & 0.466 \\
\hline Ownership & $(0.426)$ & $(0.498)$ & $(0.500)$ & $(0.451)$ & $(0.485)$ & $(0.497)$ & $(0.499)$ \\
\hline $\mathrm{N}$ & 6207 & 153043 & 21490 & 33042 & 78202 & 11444 & 2032 \\
\hline Estimated & 77696.68 & 9347.12 & 24869.48 & 64997.37 & 39746.34 & 30917.85 & 30588.63 \\
\hline Saving (CD) & $(518380.8)$ & $(168261.1)$ & $(270294.3)$ & $(462160.7)$ & $(360204.8)$ & $(364139.7)$ & $(218930.4)$ \\
\hline $\mathrm{N}$ & 5724 & 142702 & 20108 & 31110 & 73554 & 10394 & 1831 \\
\hline Estimated & 351965.6 & 42396.65 & 111993.4 & 289875.5 & 184231.1 & 142889.8 & 146193.4 \\
\hline Saving(BSR) & $(2123516)$ & $(677683.6)$ & $(1015782)$ & (1796910) & (1533987) & $(1639090)$ & $(1082429)$ \\
\hline $\mathrm{N}$ & 5754 & 142702 & 20108 & 31110 & 73554 & 10394 & 1831 \\
\hline Interest & 998.19 & 116.38 & 336.31 & 872.49 & 507.47 & 349.44 & 446.99 \\
\hline Income & $(4503.93)$ & $(1544.22)$ & $(2784.59)$ & $(4239.81)$ & $(3235.3)$ & $(2890.14)$ & $(3177.38)$ \\
\hline $\mathrm{N}$ & 5754 & 142702 & 20108 & 31110 & 73554 & 10394 & 1831 \\
\hline Birth Place Network & 0.005 & 0.068 & 0.005 & 0.003 & 0.01 & 0.002 & 0.004 \\
\hline in state & $(0.004)$ & $(0.059)$ & $(0.005)$ & $(0.003)$ & $(0.018)$ & $(0.002)$ & $(0.006)$ \\
\hline $\mathrm{N}$ & 6207 & 153053 & 21490 & 33042 & 78202 & 11444 & 2032 \\
\hline Share & 0.415 & 0.283 & 0.404 & 0.549 & 0.529 & 0.41 & 0.350 \\
\hline naturalized & $(0.493)$ & $(0.451)$ & $(0.491)$ & $(0.498)$ & $(0.499)$ & $(0.492)$ & $(0.478)$ \\
\hline $\mathrm{N}$ & 6207 & 153043 & 21490 & 33042 & 78202 & 11444 & 2032 \\
\hline \multirow[t]{2}{*}{ Age } & 45.92 & 37.65 & 40.20 & 47.44 & 42.04 & 36.73 & 38.29 \\
\hline & $(20.1)$ & $(16.41)$ & $(16.84)$ & (20.08) & $(17.54)$ & $(16.14)$ & (17.88) \\
\hline $\mathrm{N}$ & 6207 & 153043 & 21490 & 33042 & 78202 & 11444 & 2032 \\
\hline
\end{tabular}

Note: All monetary values are in real terms. The network variable captures the share of population of a state from your birth country averaged over birth continent. BSR means bank savings rate. 
Table 3: Savings Levels (CD) and Interest Income: Pre Recession and GRA period by Place of Birth

\begin{tabular}{ccccc}
\hline \hline & \multicolumn{2}{c}{ Savings $(\mathrm{CD})$} & \multicolumn{2}{c}{ Interest Income } \\
\hline Period & Pre Recession & $2007-2012$ & Pre Recession & $2007-2012$ \\
& $(1)$ & $(2)$ & $(4)$ & $(5)$ \\
\hline NANU & 39211.6 & 127085.8 & 977.3 & 1024.9 \\
SD & $(205022.2)$ & $(745265.8)$ & $(4464.4)$ & $(4554.8)$ \\
N & 3234 & 2520 & 3234 & 2520 \\
CAC & 4751.2 & 13953.84 & 120.9 & 111.8 \\
SD & $(70948.1)$ & $(227162.6)$ & $(1581.8)$ & $(1505.6)$ \\
N & 71435 & 71267 & 71435 & 71267 \\
S. America & 14914.8 & 34818.25 & 391.1 & 281.5 \\
SD & $(134646.1)$ & $(357442.1)$ & $(3165.8)$ & $(2341.2)$ \\
N & 10051 & 10057 & 10051 & 10057 \\
Europe & 38722.24 & 96218.15 & 952.2 & 777.8 \\
SD & $(209261.4)$ & $(643100.2)$ & $(4435.6)$ & $(3992.9)$ \\
N & 16893 & 14217 & 16893 & 14217 \\
Asia & 22504.28 & 55427.54 & 559.3 & 454.9 \\
SD & $(155494.7)$ & $(474601.3)$ & $(3455.8)$ & $(3002.1)$ \\
N & 35665 & 39215 & 35665 & 39215 \\
Africa & 17990.63 & 38205.16 & 525.7 & 251.2 \\
SD & $(120997.9)$ & $(446048.2)$ & $(3796.2)$ & $(2272.7)$ \\
N & 3269 & 5799 & 3269 & 5799 \\
Oceania & 22212.3 & 36681.23 & 529.1 & 387.3 \\
SD & $(153595.3)$ & $(256094.6)$ & $(3255.6)$ & $(3119.4)$ \\
N & 771 & 1060 & 771 & 1060 \\
\hline \hline
\end{tabular}


Table 4: Savings Levels: Pre and Post the Great Recession by Age Cohort (using recovered saving assuming CD accounts)

\begin{tabular}{cccc}
\hline \hline Period & & & \\
\hline & $\begin{array}{c}\text { Pre Recession } \\
(1)\end{array}$ & $\begin{array}{c}2007-2012 \\
(2)\end{array}$ & $\begin{array}{c}\text { Difference } \\
(3)\end{array}$ \\
\hline below 35 & 2953.62 & 7613.82 & 4660.2 \\
SD & $(37926.39)$ & $(11067.68)$ & \\
$\mathrm{N}$ & 55906 & 47703 & \\
$35-$ 44 years & 10187.24 & 26820.14 & 16632.9 \\
SD & $(86718.67)$ & $(318753.4)$ & \\
$\mathrm{N}$ & 35870 & 35589 & \\
$45-54$ years & 17952.93 & 46681.84 & 28728.91 \\
SD & $(124724)$ & $(434726.3)$ & \\
$\mathrm{N}$ & 24530 & 27974 & \\
$55-64$ years & 37338.39 & 73395.76 & 36057.37 \\
SD & $(226008.8)$ & $(616387.9)$ & \\
$\mathrm{N}$ & 14200 & 17219 & \\
65 and above & 46346.09 & 97975.12 & 51629.03 \\
SD & $(247664.8)$ & $(62303.2 .3)$ & \\
$\mathrm{N}$ & 15093 & 16400 & \\
\hline \hline
\end{tabular}


Table 5: Factors that are Correlated with Homeownership before the Recession and after

\begin{tabular}{|c|c|c|c|c|c|}
\hline & (1) & $\begin{array}{l}\text { With Naturalized } \\
\text { citizen } \\
(2)\end{array}$ & $\begin{array}{l}\text { Add household } \\
\text { income } \\
(3)\end{array}$ & $\begin{array}{l}\text { Add wage } \\
\text { income } \\
(4)\end{array}$ & $\begin{array}{l}\text { Add total } \\
\text { income } \\
(5)\end{array}$ \\
\hline Sex & $\begin{array}{c}0.035^{* * *} \\
(0.00)\end{array}$ & $\begin{array}{c}0.033^{* * *} \\
(0.00)\end{array}$ & $\begin{array}{c}0.039^{* * *} \\
(0.00)\end{array}$ & $\begin{array}{c}0.071^{* * *} \\
(0.00)\end{array}$ & $\begin{array}{c}0.057^{* * *} \\
(0.00)\end{array}$ \\
\hline Age & $\begin{array}{c}0.004^{* * *} \\
(0.00)\end{array}$ & $\begin{array}{c}0.004^{* * *} \\
(0.00)\end{array}$ & $\begin{array}{c}0.004^{* * *} \\
(0.00)\end{array}$ & $\begin{array}{c}0.005^{* * *} \\
(0.00)\end{array}$ & $\begin{array}{c}0.003^{* * *} \\
(0.00)\end{array}$ \\
\hline Family size & $\begin{array}{c}0.070^{* * *} \\
(0.00)\end{array}$ & $\begin{array}{c}0.070^{* * *} \\
(0.00)\end{array}$ & $\begin{array}{c}0.056^{* * *} \\
(0.00)\end{array}$ & $\begin{array}{c}0.071^{* * *} \\
(0.00)\end{array}$ & $\begin{array}{l}0.070^{* * *} \\
(0.00)\end{array}$ \\
\hline Education & $\begin{array}{c}0.018^{* * *} \\
(0.00)\end{array}$ & $\begin{array}{c}0.016^{* * *} \\
(0.00)\end{array}$ & $\begin{array}{c}0.009^{* * *} \\
(0.00)\end{array}$ & $\begin{array}{c}0.014^{* * *} \\
(0.00)\end{array}$ & $\begin{array}{c}0.017^{* * *} \\
(0.00)\end{array}$ \\
\hline Years in the U.S. & $\begin{array}{l}0.014^{* * *} \\
(0.00)\end{array}$ & $\begin{array}{c}0.011^{* * *} \\
(0.00)\end{array}$ & $\begin{array}{l}0.011^{* * *} \\
(0.00)\end{array}$ & $\begin{array}{l}0.011^{* * *} \\
(0.00)\end{array}$ & $\begin{array}{l}0.011^{* * *} \\
\quad(0.00)\end{array}$ \\
\hline Naturalized & & $\begin{array}{c}0.137^{* * *} \\
(0.00)\end{array}$ & $\begin{array}{c}0.129^{* * *} \\
(0.00)\end{array}$ & $\begin{array}{c}0.143^{* * *} \\
(0.00)\end{array}$ & $\begin{array}{c}0.132^{* * *} \\
(0.00)\end{array}$ \\
\hline Log Hhld inc & & & $\begin{array}{c}0.142^{* * *} \\
(0.00)\end{array}$ & & \\
\hline Log wage & & & & $\begin{array}{c}0.048^{* * *} \\
(0.00)\end{array}$ & \\
\hline Log total inc & & & & & $\begin{array}{c}0.015^{* * *} \\
(0.00)\end{array}$ \\
\hline Sex $\times 2007-2012$ & $\begin{array}{l}0.004 \\
(0.00)\end{array}$ & $\begin{array}{l}0.003 \\
(0.00)\end{array}$ & $\begin{array}{l}0.004 \\
(0.01)\end{array}$ & $\begin{array}{l}0.005 \\
(0.01)\end{array}$ & $\begin{array}{l}0.006 \\
(0.01)\end{array}$ \\
\hline Age $\times 2007-2012$ & $\begin{array}{l}0.000^{*} \\
(0.00)\end{array}$ & $\begin{array}{c}0.000^{*} \\
(0.00)\end{array}$ & $\begin{array}{l}0.000^{*} \\
(0.00)\end{array}$ & $\begin{array}{l}0.001 \\
(0.00)\end{array}$ & $\begin{array}{l}0.000 \\
(0.00)\end{array}$ \\
\hline Family Size× 2007 - 2012 & $\begin{array}{l}-0.011^{* * * *} \\
(0.00)\end{array}$ & $\begin{array}{l}-0.011^{* * *} \\
(0.00)\end{array}$ & $\begin{array}{l}-0.010^{* * * *} \\
(0.00)\end{array}$ & $\begin{array}{l}-0.010^{* * *} \\
(0.00)\end{array}$ & $\begin{array}{c}-0.010^{* * *} \\
(0.00)\end{array}$ \\
\hline Education $\times 2007-2012$ & $\begin{array}{l}0.001 \\
(0.00)\end{array}$ & $\begin{array}{l}0.000 \\
(0.00)\end{array}$ & $\begin{array}{r}-0.001 \\
(0.00)\end{array}$ & $\begin{array}{l}0.000 \\
(0.00)\end{array}$ & $\begin{array}{l}0.000 \\
(0.00)\end{array}$ \\
\hline Years in the U.S. $\times 2007-2012$ & $\begin{array}{c}-0.001^{* * *} \\
(0.00)\end{array}$ & $\begin{array}{c}-0.001^{* * * *} \\
(0.00)\end{array}$ & $\begin{array}{c}-0.001^{* * *} \\
(0.00)\end{array}$ & $\begin{array}{c}-0.002^{* * *} \\
(0.00)\end{array}$ & $\begin{array}{c}-0.011^{* * *} \\
(0.00)\end{array}$ \\
\hline Naturalized $\times 2007-2012$ & & $\begin{array}{r}0.010^{*} \\
(0.01)\end{array}$ & $\begin{array}{c}0.011^{*} \\
(0.01)\end{array}$ & $\begin{array}{l}0.008 \\
(0.01)\end{array}$ & $\begin{array}{l}0.008 \\
(0.01)\end{array}$ \\
\hline Log Hhld income $\times 2007-2012$ & & & $\begin{array}{c}0.011^{* *} \\
(0.00)\end{array}$ & & \\
\hline Log wage $\times 2007-2012$ & & & & $\begin{array}{c}0.007^{* *} \\
(0.00)\end{array}$ & \\
\hline Log total inc $\times 2007-2012$ & & & & & $\begin{array}{c}0.009 * * * \\
(0.00)\end{array}$ \\
\hline $\mathrm{N}$ & 290466 & 290466 & 286946 & 185487 & 240773 \\
\hline
\end{tabular}

* Note: This table summarizes the estimates of a regression model of homeownership with fixed effects for state and year. Other variables we control for not shown in the summary above are:.Employment dummies, Metro area dummies, Marital status dummies and birth continent dummies. The interaction of each of these variables and 2007-2012 dummy is also included in the analysis. ${ }^{*} p<0.05,{ }^{* *} p<0.01,{ }^{* * *} p<0.001$ 
Table 6: The Role of Savings in Homeownership before the Recession and beyond

\begin{tabular}{|c|c|c|c|c|}
\hline & $\begin{array}{l}\text { Interest Income } \\
(1) \\
\end{array}$ & $\begin{array}{c}\text { Recovered Savings } \\
\text { with CD } \\
(2) \\
\end{array}$ & $\begin{array}{l}\text { Recovered Savings } \\
\text { with Bank Interest } \\
\text { (3) }\end{array}$ & $\begin{array}{c}\text { Recovered Savings Mean of } \\
\text { CD and Bank Interest } \\
(4)\end{array}$ \\
\hline Sex & $\begin{array}{c}0.038^{* * *} \\
(0.00)\end{array}$ & $\begin{array}{c}0.038^{* * *} \\
(0.00)\end{array}$ & $\begin{array}{c}0.038^{* * *} \\
(0.00)\end{array}$ & $\begin{array}{c}0.038^{* * *} \\
(0.00)\end{array}$ \\
\hline Age & $\begin{array}{l}0.004^{* * *} \\
(0.00)\end{array}$ & $\begin{array}{c}0.004^{* * *} \\
(0.00)\end{array}$ & $\begin{array}{c}0.004^{* * *} \\
(0.00)\end{array}$ & $\begin{array}{c}0.004^{* * *} \\
(0.00)\end{array}$ \\
\hline Family size & $\begin{array}{c}0.058^{* * *} \\
(0.00)\end{array}$ & $\begin{array}{c}0.058 * * * \\
(0.00)\end{array}$ & $\begin{array}{c}0.058^{* * *} \\
(0.00)\end{array}$ & $\begin{array}{l}0.058^{* * *} \\
\quad(0.00)\end{array}$ \\
\hline Education & $\begin{array}{c}0.007^{* * * *} \\
(0.00)\end{array}$ & $\begin{array}{l}0.007 * * * \\
(0.00)\end{array}$ & $\begin{array}{l}0.007^{* * * *} \\
(0.00)\end{array}$ & $\begin{array}{l}0.007^{* * * *} \\
(0.00)\end{array}$ \\
\hline Years in the U.S. & $\begin{array}{c}0.010^{* * *} \\
(0.00)\end{array}$ & $\begin{array}{c}0.010^{* * *} \\
(0.00)\end{array}$ & $\begin{array}{c}0.010^{* * *} \\
(0.00)\end{array}$ & $\begin{array}{c}0.010^{* * *} \\
(0.00)\end{array}$ \\
\hline Naturalized & $\begin{array}{l}0.128^{* * *} \\
(0.00)\end{array}$ & $\begin{array}{l}0.127^{* * *} \\
(0.00)\end{array}$ & $\begin{array}{l}0.127^{* * *} \\
(0.00)\end{array}$ & $\begin{array}{l}0.127^{* * *} \\
(0.00)\end{array}$ \\
\hline Log Hhld inc & $\begin{array}{l}0.133^{* * *} \\
(0.00)\end{array}$ & $\begin{array}{c}0.133^{* * *} \\
(0.00)\end{array}$ & $\begin{array}{l}0.133^{* * *} \\
(0.00)\end{array}$ & $\begin{array}{l}0.133^{* * *} \\
(0.00)\end{array}$ \\
\hline Log Interest Income & $\begin{array}{c}0.016^{* * *} \\
(0.00)\end{array}$ & & & $(0.00)$ \\
\hline Log Savings CD & & $\begin{array}{l}0.011^{* * * *} \\
(0.00)\end{array}$ & & \\
\hline Log Savings BI & & & $\begin{array}{c}0.009^{* * *} \\
(0.00)\end{array}$ & \\
\hline $\begin{array}{c}\text { Log Savings mean of } \\
\text { CD and BI }\end{array}$ & & & & $\begin{array}{c}0.010^{* * *} \\
(0.00)\end{array}$ \\
\hline Sex $\times 2007-2012$ & $\begin{array}{l}0.005 \\
(0.01)\end{array}$ & $\begin{array}{l}0.005 \\
(0.01)\end{array}$ & $\begin{array}{l}0.005 \\
(0.01)\end{array}$ & $\begin{array}{l}0.005 \\
(0.01)\end{array}$ \\
\hline Age $\times 2007-2012$ & $\begin{array}{c}0.000^{* *} \\
(0.00)\end{array}$ & $\begin{array}{c}0.000^{* *} \\
(0.00)\end{array}$ & $\begin{array}{c}0.000^{* *} \\
(0.00)\end{array}$ & $\begin{array}{c}0.000^{* *} \\
(0.00)\end{array}$ \\
\hline Family Size & $-0.011 * * *$ & $-0.011 * * *$ & $-0.010^{* * *}$ & $-0.010^{* * *}$ \\
\hline$\times 2007-2012$ & $(0.00)$ & $(0.00)$ & $(0.00)$ & $(0.00)$ \\
\hline Education & -0.001 & -0.001 & -0.001 & -0.001 \\
\hline$\times 2007-2012$ & $(0.00)$ & $(0.00)$ & $(0.00)$ & $(0.00)$ \\
\hline Years in the U.S. & $-0.001^{* * *}$ & $-0.001^{* * *}$ & $-0.001^{* * *}$ & $-0.001^{* * *}$ \\
\hline$\times 2007-2012$ & $(0.00)$ & $(0.00)$ & $(0.00)$ & $(0.00)$ \\
\hline Naturalized & $0.011^{*}$ & $0.011^{*}$ & $0.011^{*}$ & $0.011^{*}$ \\
\hline$\times 2007-2012$ & $(0.01)$ & $(0.00)$ & $(0.00)$ & $(0.00)$ \\
\hline Log Hhld income & $0.013^{* * *}$ & $0.013^{* * *}$ & $0.013^{* * *}$ & $0.013^{* * *}$ \\
\hline$\times 2007-2012$ & $(0.00)$ & $(0.00)$ & $(0.00)$ & $(0.00)$ \\
\hline $\begin{array}{l}\text { Log Interest Income } \\
\quad \times 2007-2012\end{array}$ & $\begin{array}{l}-0.001 \\
(0.001)\end{array}$ & & & $\begin{array}{c}0.007^{* *} \\
(0.00)\end{array}$ \\
\hline $\begin{array}{l}\text { Log Savings CD } \\
\times 2007-2012\end{array}$ & & $\begin{array}{c}-0.002^{* *} \\
(0.00)\end{array}$ & & \\
\hline $\begin{array}{l}\text { Log Savings BI } \\
\times 2007-2012\end{array}$ & & & $\begin{array}{c}-0.001^{* *} \\
(0.00)\end{array}$ & \\
\hline $\begin{array}{l}\text { Log Savings mean of CD and BI } \\
\qquad \times 2007-2012\end{array}$ & & & & $\begin{array}{c}-0.001^{* *} \\
(0.00)\end{array}$ \\
\hline $\mathrm{N}$ & 286946 & 286946 & 286946 & 286946 \\
\hline
\end{tabular}

*Note: This table summarizes the marginal effect estimates of a probit model of homeownership. Other variables we control for not shown in the summary above are:Employment dummies, Metro area dummies, Marital status dummies, State and Year fixed effects and birth continent dummies. The interaction of each of these variables and 2007-2012 dummy is also included in the analysis. ${ }^{*} p<0.05,{ }^{* *} p<0.01,{ }^{* * *} p<0.001$ 
Table 7: The Role of Birthplace Networks in Homeownership before the Recession and beyond

\begin{tabular}{|c|c|c|c|c|}
\hline & $\begin{array}{c}\text { Interest Income } \\
\text { (1) }\end{array}$ & $\begin{array}{l}\text { Savings } \\
\text { with CD } \\
(2) \\
\end{array}$ & $\begin{array}{c}\text { Savings } \\
\text { with Bank Interest } \\
(3)\end{array}$ & $\begin{array}{l}\text { Savings from Mean of } \\
\text { CD and Bank Interest } \\
(4)\end{array}$ \\
\hline Sex & $\begin{array}{c}0.039^{* * *} \\
(0.00)\end{array}$ & $\begin{array}{c}0.038^{* * *} \\
(0.00)\end{array}$ & $\begin{array}{c}0.038^{* * *} \\
(0.00)\end{array}$ & $\begin{array}{c}0.038^{* * *} \\
(0.00)\end{array}$ \\
\hline Age & $\begin{array}{c}0.004^{* * *} \\
(0.00)\end{array}$ & $\begin{array}{c}0.004^{* * *} \\
(0.00)\end{array}$ & $\begin{array}{c}0.004^{* * *} \\
(0.00)\end{array}$ & $\begin{array}{l}0.004^{* * *} \\
(0.00)\end{array}$ \\
\hline Family size & $\begin{array}{c}0.058^{* * *} \\
(0.00)\end{array}$ & $\begin{array}{c}0.058^{* * *} \\
(0.00)\end{array}$ & $\begin{array}{c}0.058^{* * *} \\
(0.00)\end{array}$ & $\begin{array}{c}0.058^{* * *} \\
(0.00)\end{array}$ \\
\hline Education & $\begin{array}{c}0.007^{* * *} \\
(0.00)\end{array}$ & $\begin{array}{c}0.007^{* * *} \\
(0.00)\end{array}$ & $\begin{array}{c}0.007 * * * \\
(0.00)\end{array}$ & $\begin{array}{c}0.007^{* * *} \\
(0.00)\end{array}$ \\
\hline Years in the U.S. & $\begin{array}{c}0.010^{* * *} \\
(0.00)\end{array}$ & $\begin{array}{c}0.010^{* * *} \\
(0.00)\end{array}$ & $\begin{array}{c}0.010^{* * *} \\
(0.00)\end{array}$ & $\begin{array}{c}0.010^{* * *} \\
(0.00)\end{array}$ \\
\hline Naturalized & $\begin{array}{l}0.129 * * * \\
(0.00)\end{array}$ & $\begin{array}{l}0.128^{* * *} \\
(0.00)\end{array}$ & $\begin{array}{l}0.128^{* * * *} \\
(0.00)\end{array}$ & $\begin{array}{c}0.128^{* * *} \\
(0.00)\end{array}$ \\
\hline Log Hhld inc & $\begin{array}{c}0.133^{* * *} \\
(0.00)\end{array}$ & $\begin{array}{c}0.133^{* * *} \\
(0.00)\end{array}$ & $\begin{array}{c}0.133^{* * *} \\
(0.00)\end{array}$ & $\begin{array}{c}0.133^{* * *} \\
(0.00)\end{array}$ \\
\hline Log Interest Income & $\begin{array}{c}0.016^{* * *} \\
(0.00)\end{array}$ & & & $(0.00)$ \\
\hline Log Savings CD & & $\begin{array}{c}0.011^{* * *} \\
(0.00)\end{array}$ & & \\
\hline Log Savings BI & & & $\begin{array}{c}0.009 * * * \\
(0.00)\end{array}$ & \\
\hline $\begin{array}{c}\text { Log Savings mean of } \\
\text { CD and BI }\end{array}$ & & & & $\begin{array}{c}0.010^{* * *} \\
(0.00)\end{array}$ \\
\hline Birth Place Network & $\begin{array}{c}0.224^{* * *} \\
(0.05)\end{array}$ & $\begin{array}{c}0.224^{* * *} \\
(0.05)\end{array}$ & $\begin{array}{c}0.225^{* * *} \\
(0.05)\end{array}$ & $\begin{array}{c}0.225^{* * *} \\
(0.05)\end{array}$ \\
\hline Birth Place Network & $0.249^{* * *}$ & $0.248^{* * *}$ & $0.248^{* * *}$ & $0.248^{* * *}$ \\
\hline$\times 2007-2012$ & $(0.07)$ & $(0.07)$ & $(0.07)$ & $(0.07)$ \\
\hline Age $\times 2007-2012$ & $\begin{array}{c}0.001^{* *} \\
(0.00)\end{array}$ & $\begin{array}{c}0.001^{* *} \\
(0.00)\end{array}$ & $\begin{array}{c}0.001^{* *} \\
(0.00)\end{array}$ & $\begin{array}{c}0.001^{* *} \\
(0.00)\end{array}$ \\
\hline $\begin{array}{l}\text { Family Size } \\
\times 2007-2012\end{array}$ & $\begin{array}{c}-0.011^{* * * *} \\
(0.00)\end{array}$ & $\begin{array}{c}-0.011^{* * *} \\
(0.00)\end{array}$ & $\begin{array}{c}-0.010^{* * * *} \\
(0.00)\end{array}$ & $\begin{array}{c}-0.010^{* * * *} \\
(0.00)\end{array}$ \\
\hline Education & -0.000 & -0.001 & -0.001 & -0.001 \\
\hline$\times 2007-2012$ & $(0.00)$ & $(0.00)$ & $(0.00)$ & $(0.00)$ \\
\hline Years in the U.S. & $-0.001 * * *$ & $-0.001 * * *$ & $-0.001^{* * *}$ & $-0.001^{* * *}$ \\
\hline $\begin{array}{c}\times 2007-2012 \\
\text { Naturalized }\end{array}$ & $\begin{array}{l}(0.00) \\
0.012^{*}\end{array}$ & $\begin{array}{l}(0.00) \\
0.013^{*}\end{array}$ & $\begin{array}{l}(0.00) \\
0.013^{*}\end{array}$ & $\begin{array}{l}(0.00) \\
0.013^{*}\end{array}$ \\
\hline$\times 2007-2012$ & $(0.01)$ & $(0.00)$ & $(0.00)$ & $(0.00)$ \\
\hline Log Hhld income & $0.013^{* * *}$ & $0.013^{* * *}$ & $0.013^{* * *}$ & $0.013^{* * *}$ \\
\hline$\times 2007-2012$ & $(0.00)$ & $(0.00)$ & $(0.00)$ & $(0.00)$ \\
\hline Log Interest Income & -0.001 & & & $0.007^{* *}$ \\
\hline$\times 2007-2012$ & $(0.001)$ & & & $(0.00)$ \\
\hline $\begin{array}{l}\text { Log Savings CD } \\
\times 2007-2012\end{array}$ & & $\begin{array}{c}-0.002^{* *} \\
(0.00)\end{array}$ & & \\
\hline $\begin{array}{l}\text { Log Savings BI } \\
\times 2007-2012\end{array}$ & & & $\begin{array}{c}-0.001^{* *} \\
(0.00)\end{array}$ & \\
\hline $\begin{array}{l}\text { Log Savings mean of CD and BI } \\
\qquad \times 2007-2012\end{array}$ & & & & $\begin{array}{c}-0.001^{* *} \\
(0.00)\end{array}$ \\
\hline $\mathrm{N}$ & 286946 & 286946 & 286946 & 286946 \\
\hline
\end{tabular}

* Note: This table summarizes the marginal effect estimates of a probit model of homeownership. Other variables we control for not shown in the summary above are:Employment dummies, Metro area dummies, Marital status dummies, State and Year fixed effects and birth continent dummies. The interaction of each of these variables and 2007-2012 dummy is also included in the analysis. ${ }^{*} p<0.05,{ }^{* *} p<0.01, * * * p<0.001$ 
Table 8: The Role of Birthplace Networks in Homeownership for those Age 35 and above

\begin{tabular}{|c|c|c|c|c|}
\hline & $\begin{array}{c}\text { Interest Income } \\
\text { (1) }\end{array}$ & $\begin{array}{l}\text { Savings } \\
\text { with CD } \\
\text { (2) }\end{array}$ & $\begin{array}{c}\text { Savings } \\
\text { with Bank Interest } \\
(3)\end{array}$ & $\begin{array}{l}\text { Savings from Mean of } \\
\text { CD and Bank Interest } \\
\text { (4) }\end{array}$ \\
\hline Sex & $\begin{array}{c}0.047^{* * *} \\
(0.00)\end{array}$ & $\begin{array}{c}0.038^{* * *} \\
(0.00)\end{array}$ & $\begin{array}{c}0.038^{* * *} \\
(0.00)\end{array}$ & $\begin{array}{c}0.038^{* * *} \\
(0.00)\end{array}$ \\
\hline Age & $\begin{array}{c}0.003^{* * *} \\
(0.00)\end{array}$ & $\begin{array}{c}0.003^{* * *} \\
(0.00)\end{array}$ & $\begin{array}{c}0.003^{* * *} \\
(0.00)\end{array}$ & $\begin{array}{c}0.003^{* * *} \\
(0.00)\end{array}$ \\
\hline Family size & $\begin{array}{c}0.040^{* * *} \\
(0.00)\end{array}$ & $\begin{array}{c}0.040^{* * *} \\
(0.00)\end{array}$ & $\begin{array}{c}0.040^{* * *} \\
(0.00)\end{array}$ & $\begin{array}{c}0.040^{* * *} \\
(0.00)\end{array}$ \\
\hline Education & $\begin{array}{c}0.008^{* * *} \\
(0.00)\end{array}$ & $\begin{array}{c}0.008^{* * *} \\
(0.00)\end{array}$ & $\begin{array}{c}0.008^{* * * *} \\
(0.00)\end{array}$ & $\begin{array}{c}0.008^{* * * *} \\
(0.00)\end{array}$ \\
\hline Years in the U.S. & $\begin{array}{c}0.008^{* * *} \\
(0.00)\end{array}$ & $\begin{array}{c}0.008^{* * *} \\
(0.00)\end{array}$ & $\begin{array}{l}0.008^{* * *} \\
(0.00)\end{array}$ & $\begin{array}{l}0.008^{* * *} \\
(0.00)\end{array}$ \\
\hline Naturalized & $\begin{array}{c}0.116^{* * *} \\
(0.00)\end{array}$ & $\begin{array}{c}0.115^{* * *} \\
(0.00)\end{array}$ & $\begin{array}{l}0.115^{* * *} \\
(0.00)\end{array}$ & $\begin{array}{c}0.115^{* * *} \\
(0.00)\end{array}$ \\
\hline Log Hhld inc & $\begin{array}{c}0.111^{* * * *} \\
(0.00)\end{array}$ & $\begin{array}{c}0.111^{* * * *} \\
(0.00)\end{array}$ & $\begin{array}{c}0.111^{* * *} \\
(0.00)\end{array}$ & $\begin{array}{c}0.111^{* * * *} \\
(0.00)\end{array}$ \\
\hline Log Interest Income & $\begin{array}{c}0.018^{* * *} \\
(0.00)\end{array}$ & & & \\
\hline Log Savings CD & & $\begin{array}{c}0.012^{* * *} \\
(0.00)\end{array}$ & & \\
\hline Log Savings BI & & & $\begin{array}{c}0.010^{* * *} \\
(0.00)\end{array}$ & \\
\hline $\begin{array}{c}\text { Log Savings mean of } \\
\text { CD and BI }\end{array}$ & & & & $\begin{array}{c}0.011^{* * *} \\
(0.00)\end{array}$ \\
\hline Birth Place Network & $\begin{array}{l}0.392^{* * *} \\
(0.06)\end{array}$ & $\begin{array}{c}0.394^{* * *} \\
(0.06)\end{array}$ & $\begin{array}{c}0.396^{* * *} \\
(0.06)\end{array}$ & $\begin{array}{c}0.395^{* * *} \\
(0.05)\end{array}$ \\
\hline $\begin{array}{l}\text { Birth Place Network } \\
\quad \times 2007-2012\end{array}$ & $\begin{array}{c}0.097^{* * *} \\
(0.08)\end{array}$ & $\begin{array}{c}0.095^{* * *} \\
(0.08)\end{array}$ & $\begin{array}{c}0.095^{* * *} \\
(0.08)\end{array}$ & $\begin{array}{c}0.095^{* * * *} \\
(0.08)\end{array}$ \\
\hline Age $\times 2007-2012$ & $\begin{array}{c}0.001^{* *} \\
(0.00)\end{array}$ & $\begin{array}{c}0.001^{* *} \\
(0.00)\end{array}$ & $\begin{array}{c}0.001^{* *} \\
(0.00)\end{array}$ & $\begin{array}{c}0.001^{* *} \\
(0.00)\end{array}$ \\
\hline Family Size & $-0.011^{* * *}$ & $-0.011^{* * *}$ & $-0.010^{* * *}$ & $-0.010^{* * *}$ \\
\hline$\times 2007-2012$ & $(0.00)$ & $(0.00)$ & $(0.00)$ & $(0.00)$ \\
\hline Education & -0.000 & -0.000 & -0.000 & -0.000 \\
\hline$\times 2007-2012$ & $(0.00)$ & $(0.00)$ & $(0.00)$ & $(0.00)$ \\
\hline Years in the U.S. & -0.000 & -0.000 & $-0.000^{*}$ & $-0.000^{*}$ \\
\hline$\times 2007-2012$ & $(0.00)$ & $(0.00)$ & $(0.00)$ & $(0.00)$ \\
\hline Naturalized & $0.003^{*}$ & 0.003 & 0.003 & 0.003 \\
\hline$\times 2007-2012$ & $(0.01)$ & $(0.01)$ & $(0.01)$ & $(0.01)$ \\
\hline Log Hhld income & $0.013^{* * *}$ & $0.013^{* * *}$ & $0.013^{* * *}$ & $0.013^{* * *}$ \\
\hline$\times 2007-2012$ & $(0.00)$ & $(0.00)$ & $(0.00)$ & $(0.00)$ \\
\hline Log Interest Income & -0.002 & & & $0.007^{* *}$ \\
\hline$\times 2007-2012$ & $(0.001)$ & & & $(0.00)$ \\
\hline $\begin{array}{l}\text { Log Savings CD } \\
\times 2007-2012\end{array}$ & & $\begin{array}{l}-0.002^{* *} \\
(0.00)\end{array}$ & & \\
\hline $\begin{array}{l}\text { Log Savings BI } \\
\times 2007-2012\end{array}$ & & & $\begin{array}{c}-0.001^{* *} \\
(0.00)\end{array}$ & \\
\hline $\begin{array}{l}\text { Log Savings mean of CD and BI } \\
\times 2007-2012\end{array}$ & & & & $\begin{array}{c}-0.001^{* *} \\
(0.00)\end{array}$ \\
\hline $\mathrm{N}$ & 286946 & 286946 & 286946 & 286946 \\
\hline
\end{tabular}

**Note: This table summarizes the marginal effect estimates of a probit model of homeownership for those 35 and above. With a focus on the change in the impact of network on the probability of home ownership. Other variables we control for not shown in the summary above are: Employment dummies, Metro area dummies, Marital status dummies, State and Year fixed effects and birth continent dummies. The interaction of each of these variables and 2007-2012 dummy is also included in the analysis. ${ }^{*} p<0.05$, ** $p<0.01,{ }^{* * *} p<0.001$ 
Table 9: Does the role of Birth Place Networks differ with the Citizenship and Years in the U.S.?

\begin{tabular}{|c|c|c|c|c|}
\hline & $\begin{array}{c}\text { Interest Income } \\
\text { (1) }\end{array}$ & $\begin{array}{l}\text { Savings } \\
\text { with CD } \\
(2)\end{array}$ & $\begin{array}{c}\text { Savings } \\
\text { with Bank Interest } \\
(3)\end{array}$ & $\begin{array}{l}\text { Savings from Mean of } \\
\text { CD and Bank Interest } \\
(4)\end{array}$ \\
\hline \multicolumn{5}{|c|}{ Panel A: Does the effect of Birthplace Network differ across Citizenship } \\
\hline Citizenship & $\begin{array}{c}0.120^{* * *} \\
(0.00)\end{array}$ & $\begin{array}{c}0.120^{* * *} \\
(0.00)\end{array}$ & $\begin{array}{c}0.120^{* * *} \\
(0.00)\end{array}$ & $\begin{array}{c}0.120^{* * *} \\
(0.00)\end{array}$ \\
\hline $\begin{array}{c}\text { Birth Place Network } \\
\text { (BPN) }\end{array}$ & $\begin{array}{c}0.155^{* * *} \\
(0.05)\end{array}$ & $\begin{array}{c}0.157^{* * *} \\
(0.05)\end{array}$ & $\begin{array}{c}0.159^{* * *} \\
(0.05)\end{array}$ & $\begin{array}{c}0.159^{* * *} \\
(0.05)\end{array}$ \\
\hline $\begin{array}{c}\text { Citizenship } \times \\
\text { Birth Place Network }\end{array}$ & $\begin{array}{c}0.257^{* * *} \\
(0.07)\end{array}$ & $\begin{array}{l}0.250^{* * *} \\
(0.07)\end{array}$ & $\begin{array}{l}0.248^{* * *} \\
(0.07)\end{array}$ & $\begin{array}{l}0.249^{* * *} \\
(0.07)\end{array}$ \\
\hline $\begin{array}{l}\text { Citizenship } \times \\
2007-2012\end{array}$ & $\begin{array}{l}0.013^{*} \\
(0.01)\end{array}$ & $\begin{array}{l}0.013^{*} \\
(0.01)\end{array}$ & $\begin{array}{l}0.013^{*} \\
(0.01)\end{array}$ & $\begin{array}{l}0.013^{*} \\
(0.01)\end{array}$ \\
\hline $\begin{array}{c}\text { Birth Place Network } \times \\
2007-2012\end{array}$ & $\begin{array}{l}0.242^{* * *} \\
\quad(0.08)\end{array}$ & $\begin{array}{c}0.240^{* * *} \\
(0.08)\end{array}$ & $\begin{array}{l}0.240^{* * *} \\
(0.08)\end{array}$ & $\begin{array}{l}0.241^{* * *} \\
(0.08)\end{array}$ \\
\hline $\begin{array}{c}\text { Citizenship } \times \\
\text { BPN } \times 2007-2012\end{array}$ & $\begin{array}{l}-0.024 \\
(0.10)\end{array}$ & $\begin{array}{l}-0.019 \\
(0.10)\end{array}$ & $\begin{array}{l}-0.020 \\
(0.10)\end{array}$ & $\begin{array}{l}-0.020 \\
(0.10)\end{array}$ \\
\hline \multicolumn{5}{|c|}{ Panel B: Does the effect of Birthplace Network differ with Years in the U.S. } \\
\hline Recent Immigrant & $\begin{array}{c}0.017^{* *} \\
(0.01)\end{array}$ & $\begin{array}{c}0.017^{* *} \\
(0.01)\end{array}$ & $\begin{array}{c}0.016^{* *} \\
(0.01)\end{array}$ & $\begin{array}{c}0.016^{* *} \\
(0.01)\end{array}$ \\
\hline $\begin{array}{c}\text { Birth Place Network } \\
\text { (BPN) }\end{array}$ & $\begin{array}{c}0.372^{* * *} \\
(0.07)\end{array}$ & $\begin{array}{c}0.367^{* * *} \\
(0.07)\end{array}$ & $\begin{array}{c}0.366^{* * *} \\
(0.07)\end{array}$ & $\begin{array}{c}0.367^{* * *} \\
(0.07)\end{array}$ \\
\hline $\begin{array}{l}\text { Recent Immigrant } \times \\
\text { Birth Place Network }\end{array}$ & $\begin{array}{c}-0.230 * * * \\
(0.07)\end{array}$ & $\begin{array}{c}-0.222^{* *} \\
(0.07)\end{array}$ & $\begin{array}{c}-0.220^{* * *} \\
(0.07)\end{array}$ & $\begin{array}{c}-0.221^{* * *} \\
(0.07)\end{array}$ \\
\hline $\begin{array}{c}\text { Recent Immigrant } \times \\
2007-2012\end{array}$ & $\begin{array}{l}0.013 \\
(0.01)\end{array}$ & $\begin{array}{l}0.013 \\
(0.01)\end{array}$ & $\begin{array}{l}0.013 \\
(0.01)\end{array}$ & $\begin{array}{l}0.013 \\
(0.01)\end{array}$ \\
\hline $\begin{array}{c}\text { Birth Place Network } \times \\
2007-2012\end{array}$ & $\begin{array}{l}0.294^{* * *} \\
(0.09)\end{array}$ & $\begin{array}{c}0.297^{* * *} \\
(0.09)\end{array}$ & $\begin{array}{l}0.298^{* * *} \\
(0.09)\end{array}$ & $\begin{array}{l}0.298^{* * *} \\
(0.09)\end{array}$ \\
\hline $\begin{array}{l}\text { Recent Immigrant } \times \\
\text { BPN } \times 2007-2012\end{array}$ & $\begin{array}{l}-0.128 \\
(0.09)\end{array}$ & $\begin{array}{l}-0.135 \\
(0.09)\end{array}$ & $\begin{array}{l}-0.136 \\
(0.09)\end{array}$ & $\begin{array}{l}-0.136 \\
(0.09)\end{array}$ \\
\hline $\mathrm{N}$ & 286946 & 286946 & 286946 & 286946 \\
\hline
\end{tabular}

\footnotetext{
**Note: This table summarizes the marginal effect estimates of a probit model of homeownership. With a focus on the change in the impact of network interacted with citizenship status or network interacted with whether an individual is a new immigrant (less than 20 years in the U.S). Other variables we control for not shown in the summary above are:Age, Education, Years in the U.S, Savings (4 proxies), Citizenship status, Gender, Employment dummies, Metro area dummies, Marital status dummies, State and Year fixed effects and birth continent dummies. The interaction of each of these variables with a 2007-2012 dummy is also included in the analysis. ${ }^{*} p<0.05,{ }^{* *} p<0.01,{ }^{* * *} p<0.001$
} 
Table 10: Does the Role of Birthplace Networks differ with Birth Place Region?

\begin{tabular}{|c|c|c|c|c|}
\hline & $\begin{array}{c}\text { Interest Income } \\
\text { (1) }\end{array}$ & $\begin{array}{l}\text { Savings } \\
\text { with CD } \\
\text { (2) }\end{array}$ & $\begin{array}{c}\text { Savings } \\
\text { with Bank Interest } \\
\text { (3) }\end{array}$ & $\begin{array}{l}\text { Savings from Mean of } \\
\text { CD and Bank Interest } \\
\text { (4) }\end{array}$ \\
\hline Birth Place Network & $\begin{array}{l}0.042 \\
(0.04)\end{array}$ & $\begin{array}{l}0.041 \\
(0.04)\end{array}$ & $\begin{array}{l}0.043 \\
(0.04)\end{array}$ & $\begin{array}{l}0.043 \\
(0.04)\end{array}$ \\
\hline Birth Place Region 1 & $\begin{array}{l}0.070^{* * *} \\
(0.00)\end{array}$ & $\begin{array}{c}0.071^{* * *} \\
(0.00)\end{array}$ & $\begin{array}{c}0.070^{* * *} \\
(0.00)\end{array}$ & $\begin{array}{c}0.070^{* * *} \\
(0.00)\end{array}$ \\
\hline Birth Place Region 2 & $\begin{array}{c}0.092^{* * *} \\
(0.01)\end{array}$ & $\begin{array}{c}0.093^{* * *} \\
(0.01)\end{array}$ & $\begin{array}{c}0.092^{* * *} \\
(0.01)\end{array}$ & $\begin{array}{c}0.092^{* * *} \\
(0.01)\end{array}$ \\
\hline $\begin{array}{l}\text { Birth Place Network } \\
\times \text { Birth Place Region } 1\end{array}$ & $\begin{array}{c}1.123^{* * *} \\
(0.26)\end{array}$ & $\begin{array}{c}1.120^{* * *} \\
(0.26)\end{array}$ & $\begin{array}{c}1.122^{* * *} \\
(0.26)\end{array}$ & $\begin{array}{c}1.122^{* * *} \\
(0.26)\end{array}$ \\
\hline BPN & $2.555^{* * *}$ & $2.588^{* * *}$ & $2.556^{* * *}$ & $2.552^{* * *}$ \\
\hline$\times$ Birth Place Region 2 & $(1.10)$ & $(1.10)$ & $(1.10)$ & $(1.10)$ \\
\hline BPN & $0.204^{* * *}$ & $0.204^{* * *}$ & $0.204^{* * *}$ & $0.204^{* * *}$ \\
\hline$\times 2007-2012$ & $(0.05)$ & $(0.05)$ & $(0.05)$ & $(0.05)$ \\
\hline $\begin{array}{l}\text { Birth Place Region } 1 \\
\quad \times 2007-2012\end{array}$ & $\begin{array}{c}0.012^{*} \\
(0.01)\end{array}$ & $\begin{array}{c}0.012^{*} \\
(0.01)\end{array}$ & $\begin{array}{c}0.012^{*} \\
(0.01)\end{array}$ & $\begin{array}{r}0.012^{*} \\
(0.01)\end{array}$ \\
\hline Birth Place Region 2 & $0.023^{* * *}$ & $0.023^{* * *}$ & $0.023^{* * *}$ & $0.023^{* * *}$ \\
\hline$\times 2007-2012$ & $(0.01)$ & $(0.01)$ & $(0.01)$ & $(0.01)$ \\
\hline $\mathrm{BPN}$ & -0.309 & -0.297 & -0.310 & -0.310 \\
\hline$\times$ Region $1 \times 2007-2012$ & $(0.34)$ & $(0.34)$ & $(0.34)$ & $(0.34)$ \\
\hline $\mathrm{BPN}$ & -0.653 & -0.709 & -0.680 & -0.682 \\
\hline$\times$ Region $2 \times 2007-2012$ & $(1.68)$ & $(1.68)$ & $(1.68)$ & $(1.68)$ \\
\hline $\mathrm{N}$ & 286946 & 286946 & 286946 & 286946 \\
\hline
\end{tabular}

**Note: This table summarizes the marginal effect estimates of a linear probability model of homeownership. With a focus on the change in the impact of network interacted with birthplace region, on the probability of home ownership. Other variables we control for not shown in the summary above are:Age, Education, Years in the U.S, Savings (4 proxies), Citizenship status, Gender, Employment dummies, Metro area dummies, Marital status dummies, State and Year fixed effects and birth continent dummies. The interaction of each of these variables with a 2007-2012 dummy is also included in the analysis. The base group is a combination of CAC and South America, Region 1 is Asia and Region 2 is a combination of Europe, Oceania and NANU $p<0.05,{ }^{* *} p<0.01,{ }^{* * *} p<0.001$ 